\title{
Microbial contributions to oxalate metabolism in health and disease
}

5 Menghan Liu ${ }^{1,2}$, Joseph C. Devlin ${ }^{1,2}$, Jiyuan $\mathrm{Hu}^{1}$, Angelina Volkova ${ }^{1,2}$, Thomas W.

6 Battaglia ${ }^{1}$, Allyson Byrd ${ }^{3}$, P'ng Loke ${ }^{1}$, Huilin $\mathrm{Li}^{1}$, Kelly V. Ruggles ${ }^{1}$, Aristotelis Tsirigos ${ }^{1}$,

7 Martin J. Blaser ${ }^{4 *}$, Lama Nazzal ${ }^{1 *}$

$8{ }^{1}$ NYU Langone Health, NY 10016, USA.

$9 \quad{ }^{2}$ Sackler Institute of Graduate Biomedical Sciences, NY 10016, USA.

$10{ }^{3}$ Department of Cancer Immunology, Genentech Inc., South San Francisco, CA 94080, USA.

$11{ }^{4}$ Center for Advanced Biotechnology and Medicine, Rutgers University, NJ 08854, USA.

12 * Correspondence to martin.blaser@cabm.rutgers.edu and lama.nazzal@nyulangone.org

13

14 
medRxiv preprint doi: https://doi.org/10.1101/2020.01.27.20018770; this version posted January 29, 2020. The copyright holder for this preprint

(which was not certified by peer review) is the author/funder, who has granted medRxiv a license to display the preprint in perpetuity.

It is made available under a CC-BY-NC 4.0 International license.

16 Table of Contents

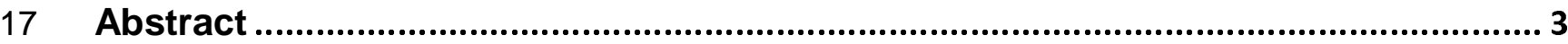

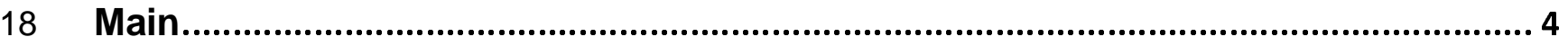

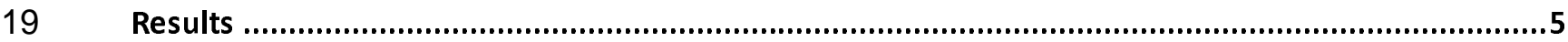

$20 \quad$ Type I and type II microbial oxalate degradation pathways (ODP) ................................................

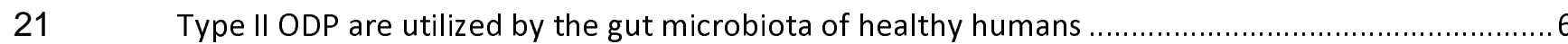

22 ODPs are encoded by multiple microbes, but dominantly expressed by Oxalobacter formigenes in healthy human microbiota

Impaired microbiota-based oxalate degradation and elevated enteric oxalate levels in IBD patients 9 


\section{Abstract}

37 Over-accumulation of oxalate in humans may lead to nephrolithiasis and nephrocalcinosis.

38 Humans lack endogenous oxalate degradation pathways (ODP), but intestinal microbiota can

39 degrade oxalate and protect against its absorption. However, the particular microbes that

40 actively degrade oxalate in vivo are ill-defined, which restricts our ability to disentangle the

41 underlying taxonomic contributions. Here we leverage large-scale multi-omics data (>3000

42 samples from $>1000$ subjects) to show that the human microbiota in health harbors diverse

43 ODP-encoding microbial species, but an oxalate autotroph-Oxalobacter formigenes- dominates

44 this function transcriptionally. Patients with Inflammatory Bowel Disease (IBD) are at

45 significantly increased risk for disrupted oxalate homeostasis and calcium-oxalate

46 nephrolithiasis. Here, by analyzing multi-omics data from the iHMP-IBD study, we demonstrate

47 that the oxalate degradation function conferred by the intestinal microbiota is severely impaired

48 in IBD patients. In parallel, the enteric oxalate levels of IBD patients are significantly elevated

49 and associated with intestinal disease severity, which is consistent with the clinically known

50 nephrolithiasis risk. The specific changes in ODP expression by several important taxa suggest

51 that they play different roles in the IBD-induced nephrolithiasis risk. 
medRxiv preprint doi: https://doi.org/10.1101/2020.01.27.20018770; this version posted January 29, 2020. The copyright holder for this preprint (which was not certified by peer review) is the author/funder, who has granted medRxiv a license to display the preprint in perpetuity.

It is made available under a CC-BY-NC 4.0 International license .

\section{Main}

54 Oxalate is a two-carbon molecule broadly present in nature [1]. In humans, oxalate from dietary

55 sources can be absorbed through the gastrointestinal tract or produced endogenously from

56 hepatic metabolism, and chiefly excreted into the urine. Lacking endogenous oxalate-

57 metabolizing enzymes, all mammals are vulnerable to oxalate toxicity, which manifests as

58 nephrolithiasis, nephrocalcinosis, chronic kidney disease (CKD), and rarely as life-threatening

59 systemic oxalosis [2-5]. Nephrolithiasis affect $8 \%$ of the US population $[6,7]$ with an $~ 20 \% 5-$

60 year recurrence rate $[8,9]$, and most kidney stones $(85-90 \%)$ are composed of calcium

61 oxalate[10]. Oxalate also has been implicated in inflammation and CKD progression, suggesting

62 broad impact [11-14].

63 The mammalian intestinal microbiota can partially protect against oxalate toxicity by oxalate

64 degradation [15-18]. Two recent large-scale epidemiological studies associated antibiotic use

65 with increased nephrolithiasis risk [19, 20], presumably via a perturbed microbiota [21]. Multiple

66 gut microbes can degrade oxalate [22], including Oxalobacter formigenes, an oxalate autotroph

67 [23-27]. When given to animals, O. formigenes has reduced host oxalate burden [28-33].

68 Escherichia coli, Bifidobacterium spp. and Lactobacillus spp. also can degrade oxalate [34-43],

69 but it is unclear which organisms are active oxalate degraders in vivo. A better understanding of

70 human oxalate degrading microbes is needed to develop clinically protective strategies.

71 In particular, Inflammatory Bowel Disease (IBD) patients have heightened risk of oxalate toxicity

72 due to elevated enteric oxalate levels and oxalate hyperabsorption, termed enteric

73 hyperoxaluria (EH) [44-46]. Nephrolithiasis occurs in $12 \%-28 \%$ of adult IBD patients [44, 45].

74 Multiple factors are associated with EH in IBD patients, including lipid malabsorption and

75 increased gut permeability. Another hypothesis is that microbiota-based oxalate degradation is

76 impaired in IBD patients, leading to increased oxalate absorption [16]. 
medRxiv preprint doi: https://doi.org/10.1101/2020.01.27.20018770; this version posted January 29, 2020. The copyright holder for this preprint (which was not certified by peer review) is the author/funder, who has granted medRxiv a license to display the preprint in perpetuity.

It is made available under a CC-BY-NC 4.0 International license .

77 Here, we leveraged large-scale multi-omics data to study oxalate degradation in the human

78 microbiota. We curated all known microbial oxalate degradation pathways and identified those

79 present in the human microbiota, and those that were transcriptionally active. We also

80 interrogated the microbiota of IBD patients to understand shifts in microbiota-based oxalate

81 degradation functions and their metabolic consequences.

82 Results

83

84 Type I and type II microbial oxalate degradation pathways (ODP)

85 To determine the ODP used by human gut bacteria, we curated all experimentally-validated

86 microbial ODP from literature review and database searches (KEGG, MetaCyc, and Brenda)

87 (Fig. 1A) [47-53]. There are two types of ODP based on their enzymatic mechanisms and co-

88 factor requirements. Type I ODP cleave the oxalate carbon-carbon (C-C) bond in a single step

89 (Fig. 1A) with no cofactor required. The two type I enzymes oxalate oxidase and oxalate

90 decarboxylase (Fig. 1A) [54-57] are indistinguishable at the amino acid level [58] and belong to

91 a single UniProt homologous protein family (IPR017774), therefore we refer to them jointly as

92 oxalate oxidase/decarboxylase (OXDD). Type II ODP consists of two enzymatic reactions

93 requiring coenzyme $A$ as co-factor (Fig. 1A). Initially, coenzyme $A$ is added to oxalate to form

94 oxalyl-CoA, e.g. by formyl-CoA transferase (FRC) (Fig. 1A). In the second step, all type II ODP

95 use oxalyl-CoA decarboxylase $(\mathrm{OXC})$ to metabolize oxalyl-CoA into $\mathrm{CO}_{2}$ and formyl-CoA (Fig.

96 1A).

97 As such, we then acquired all available protein homologs of OXDD ( $n=2836)$, FRC $(n=1947)$,

98 and OXC $(n=1284)$ from UniProt Interpro $[59,60]$. By tracing the taxonomic origin of the genes

99 encoding those homologs, we found that OXDD-coding taxa can be fungal or bacterial, whereas

100 FRC- and OXC-coding taxa are strictly bacterial (Fig. 1B). The frequent co-occurrence of FRC

101 and OXC in individual genomes indicates encoding complete type II ODPs (Fig. 1B). As

102 expected, OXDD, FRC, and OXC each are conserved within the same microbial class, but 
medRxiv preprint doi: https://doi.org/10.1101/2020.01.27.20018770; this version posted January 29, 2020. The copyright holder for this preprint (which was not certified by peer review) is the author/funder, who has granted medRxiv a license to display the preprint in perpetuity.

It is made available under a CC-BY-NC 4.0 International license .

103 exhibit substantial divergence across individual classes (Fig. S1). These data provide a

104 comprehensive overview of ODP pathways and a reference set of ODP-encoding microbes, 105 which enable analyses to elucidate those relevant to humans.

\section{Type II ODP are utilized by the gut microbiota of healthy humans}

Next, we ask which of these ODP are encoded and expressed within the metagenomes and metatranscriptomes of healthy humans (Fig. S2). Multi-omics data from five studies were selected for downstream analyses, collectively including 2359 metagenome samples and 1053 metatranscriptome samples from 660 and 165 subjects, respectively (Fig. S2, Table S1). After removing host-associated and low-quality reads, using DIAMOND Blastx [61] all remaining sequences were compared with the unique oxalate-degrading enzyme (ODE) homologous

114 proteins, including 2519 OXDD, 1556 FRC, and 1037 OXC homologs. Alignment pairs with 115 identity $>90 \%$ were retained for downstream analyses; this cut-off was determined by the

116 protein identity of the inter- and intra-species ODEs to be robust for distinguishing ODEs that 117 originated from different microbial species (Fig. S3).

118 We found that ODEs were ubiquitously harbored in the healthy gut microbiome; at least one 119 ODE was detected in the metagenome of 607 (92\%) of the 660 subjects examined, and in the 120 metatranscriptome of $132(80 \%)$ of the 165 subjects available. In the metagenomes, the type II 121 ODE FRC- and OXC-encoding genes frc and oxc were substantially more prevalent (Fig. 2A), 122 and more abundant (Fig. 2B) than the type I ODE OXDD-coding gene oxdd. Similarly, in the 123 metatranscriptomes, frc and oxc expression also were substantially more prevalent (Fig. 2C), 124 and abundant (Fig. 2D) than oxdd expression. These findings were consistent in all studies, 125 despite differences in source populations and sample preparation methods (Table S1). In 126 addition, specific frc and oxc genes (Fig. S4) were frequently co-expressed within the same 127 microbiota, indicating the expression of the complete type II ODP. In total, these data indicate 
medRxiv preprint doi: https://doi.org/10.1101/2020.01.27.20018770; this version posted January 29, 2020. The copyright holder for this preprint (which was not certified by peer review) is the author/funder, who has granted medRxiv a license to display the preprint in perpetuity.

It is made available under a CC-BY-NC 4.0 International license .

128 that the human microbiome is commonly and predominantly composed of microbes utilizing

129 type II rather than type I ODP. As such, we focused on the type II ODP for the remaining 130 analyzes.

ODPs are encoded by multiple microbes, but dominantly expressed by

\section{Oxalobacter formigenes in healthy human microbiota}

134 Although multiple microbes are known to encode frc and oxc [22, 62-64], their functional activity 135 in vivo has not been studied. We next systematically characterized the active oxalate degraders 136 in vivo by searching for the microbial species that transcribe these type II ODP genes. In the 137 metagenome of 660 healthy subjects, we detected oxc encoded by multiple human gut 138 microbes including E. coli, O. formigenes, Muribaculaceae sp, and several Bifidobacterium sp., 139 Lactobacillus sp, (Fig. 3A, left), some of which have been reported to degrade oxalate [31, 34$14037,41-43,62,65,66]$. The abundance of oxc of those species varied widely (median RPKM of 141 0.006-0.223) (Fig. 3A, left). The most prevalent oxc-encoding microbe was E. coli (oxc detected 142 in $56 \%$ of subjects), followed by 0 . formigenes (oxc detected in $39 \%$ ). The abundance and 143 prevalence pattern for oxc was consistent across different studies (Fig. S5, S6), and was 144 parallel to the other type II ODE frc (Fig. S7),

145 Surprisingly, oxc expression across species did not directly correlate with oxc metagenomic 146 abundance or prevalence (Fig. 3A, right). For O. formigenes, whose growth relies on oxalate 147 degradation [23, 67, 68], oxc expression was both most abundant and most prevalent, present 148 in the metatranscriptome of $61 \%$ of subjects (Fig. 3A, right). In contrast, E. coli oxc expression 149 was observed in only $12 \%$ of subjects (Fig. 3A, right), despite gene presence in $56 \%$ of 150 subjects (Fig. 3A, left). For Bifidobacterium and Lactobacillus species, whose oxalate 151 degradation activity was reported in vitro and in animal models [42, 43, 66], oxc expression was 152 observed at low prevalence (<5\%), or not observed at all (B. pseudocatenulatum, B. choerinum) 
medRxiv preprint doi: https://doi.org/10.1101/2020.01.27.20018770; this version posted January 29, 2020. The copyright holder for this preprint (which was not certified by peer review) is the author/funder, who has granted medRxiv a license to display the preprint in perpetuity.

It is made available under a CC-BY-NC 4.0 International license .

153 (Fig. 3A right). Collectively, these data demonstrate variation in the extent of ODP transcription

154 by species and individual hosts.

155 To test the species-specific expression pattern of ODP in a more rigorous manner, we restricted

156 our analysis to the subject-matched metagenome and metatranscriptome that derived from the

157 same microbiota communities (Fig. 3B). O. formigenes ODP expression was observed in most

158 subjects whose microbiome harbored the corresponding gene (Fig. 3B), and in many subjects

159 in whom the gene was not detected, indicating underdectection of $O$. formigenes ODP at the

160 genomic level. In contrast, E. coli ODP expression was only observed in a small portion of

161 subjects harboring the corresponding genes (Fig. 3B). The relative lack of detection of $O$.

162 formigenes ODP genes in the metagenomic data may reflect the highly variable abundance of

163 the organism itself falling at times below the lower limit of detection using genetic-based

164 methods [69-72].

165 We then assessed population-level contribution (see Methods) to quantify the impact of

166 individual species on global ODP. The contribution of $O$. formigenes to ODP increased from $17 \%$

167 to $63 \%$ from the metagenomic to the metatranscriptomic level, greater than the transcriptomic

168 contributions of all other species combined (Fig. 3C, Table S2). Conversely, the contribution of

169 E. coli to ODP was markedly reduced from the metagenomic (36\%) to the metatranscriptomic

170 (7\%) level (Fig. 3C). The contributions of other species to ODP at the metagenomic and

171 metatranscriptomic levels varied, but none were dominant (Fig. 3C). A parallel pattern was

172 observed for frc (Fig. S8, Table S3). Network analysis did not yield significant species-species

173 interactions related to oxc transcription, potentially because the activity of non- $O$. formigenes

174 species was too low across the studies (data not shown).

175 In summary, we systematically described the gut microbes responsible for oxalate degradation

176 in vivo in health, showing that this microbial function is dominated by a single species- $O$.

177 formigenes. These data provide a baseline for examining the disease-associated changes in

178 subsequent analyses. 
medRxiv preprint doi: https://doi.org/10.1101/2020.01.27.20018770; this version posted January 29, 2020. The copyright holder for this preprint (which was not certified by peer review) is the author/funder, who has granted medRxiv a license to display the preprint in perpetuity.

It is made available under a CC-BY-NC 4.0 International license .

179 Impaired microbiota-based oxalate degradation and elevated enteric oxalate 180 levels in IBD patients

181 IBD patients frequently suffer from Enteric Hyperoxaluria $(\mathrm{EH})$, with oxalate hyperabsorption 182 and formation of calcium oxalate kidney stones [44-46]. In particular, Crohn's disease (CD) with 183 ileocolonic involvement is associated with greater nephrolithiasis risk compared to either ileal or 184 colonic involvement alone [73]; Ulcerative colitis (UC), regardless of severity and location, is 185 associated with stone formation [73]. We hypothesized that the oxalate degradation function 186 conferred by the intestinal microbiome may be impaired in IBD patients, ultimately leading to 187 more intestinal and circulating oxalate in the host. To address this question, we acquired the 188 multi-omics iHMP-IBD study data $[74,75]$ to assess both oxalate homeostasis and microbiota189 based oxalate degradation.

190 We stratified the iHMP-IBD patients into UC $(\mathrm{N}=30), \mathrm{CD}(\mathrm{N}=54)$ groups, regardless of the 191 disease location, and a CD subgroup with the ileocolonic phenotype at baseline - CD-L3 ( $n=25)$.

192 Consistent with the clinical nephrolithiasis risk, fecal oxalate concentrations were elevated in 193 both the UC patients $(p=0.005)$ and CD-L3 patients $(p<0.001)$ compared to healthy controls; the 194 same trend was observed in the $C D$ patients $(p=0.06)$ (Fig. 4A). Fecal oxalate was most 195 increased in the CD-L3 patients (Fig. 4A, Fig. S9). We also examined the differences in fecal 196 oxalate concentrations in a linear mixed-effects model, adjusted for subject age, and sex as 197 fixed effects and repeated measurements as a random effect, and observed the effects at 198 marginal levels ( $p=0.095$ for $C D, p=0.083$ for UC, $p=0.058$ for $C D-L 3$ ).

199 Expression of frc in the gut microbiota was only observed in $50 \%$ of UC $(p<0.05), 65 \%$ of CD 200 and $64 \%$ of CD-L3 patients compared to $76 \%$ in healthy subjects (Fig. 4B), and the levels of 201 expression were significantly decreased in all IBD groups $(p<0.001)$ (Fig. 4C). Similarly, oxc 202 expression was observed in 57\% UC, 54\% CD and 48\% CD-L3 patients (Fig. 4B) compared to $20371 \%$ in healthy persons, and was significantly downregulated in the UC group $(p<0.001)$ (Fig. 
204 4C). Type I ODE oxdd was rarely observed in the IBD microbiota, similar to healthy persons 205 (data not shown).

206 We then asked whether there was a relationship between the decreased microbiota-based ODP 207 expression and oxalate levels in the intestinal tract. By Spearman correlation, 44\%-57\% of the

208 variance in fecal oxalate could be explained by variation in ODP expression in IBD patients 209 ( $p<0.05$ for UC and CD-L3 subjects) (Fig 4D). In contrast, microbial ODP genes showed 210 increased abundance in IBD patients (Fig. S10 A, B), indicating the discrepancies between the 211 gene abundance and expression levels.

212 Collectively, these data indicate that IBD patients have decreased microbiota-based oxalate 213 degradation; the observed elevated intestinal oxalate may be a consequence, conferring 214 increased susceptibility to $\mathrm{EH}$.

\section{Loss of 0 . formigenes and downregulation of its ODP in IBD patients}

217 We next sought to identify which microbial species accounted for the reduced ODP expression 218 in IBD patients. The two species $E$. coli and O. formigenes with the largest ODP contributions at 219 the genomic and transcriptional level, respectively, were notable.

220 Using gene and transcript jointly as markers, ODP expression by 0 . formigenes was detected in 221 only $\sim 25 \%$ in UC and in CD patients (Fig. 5A) - less prevalent than the $\sim 70 \%$ in healthy 222 individuals, either when studies were combined (Fig. 5A) or separate (Fig. 3D). Having the 223 lowest $O$. formigenes prevalence, the CD-L3 group had strongest negative correlation between 224 fecal oxalate and expression of oxc (Fig. 4D). Consistent with the low prevalence, the ODP 225 expression by 0 . formigenes was also less abundant in UC, CD, and in CD-L3 patients 226 compared with controls ( $p<0.01$ for all groups), marked by lower RPKM values (Fig. 5B), 227 Interestingly, O. formigenes ODP was always actively expressed, when genes were observed, 228 within the microbiota of the IBD subjects (Fig. 5A). In contrast, the ODP of E. coli was detected 
229 in nearly all IBD subjects and was transcribed more frequently compared to healthy subjects

230 (Fig. 5A).

231 In total, these data revealed the complex pattern of taxa-specific ODP expression change during

232 a disease state. In particular, the contrasting patterns of $O$. formigenes and $E$. coli illustrate the

233 varied responses in association with distinct disease progression. Abolishing the ODP

234 expression of $O$. formigenes, leads to the impaired global oxalate degradation, which further

235 leads to increased circulating oxalate. Although E. coli, Lactobacillus spp, and Bifidobacterium

236 spp, use their ODPs to defend against oxalate-induced acid stress [34, 41, 62, 64, 66], their

237 upregulated ODP in IBD is a secondary response to the elevated oxalate levels present.

\section{Discussion}

Oxalate degradation by the human microbiota has been known since the 1940 s $[15,17,18,49$,

$24368,76,77]$, but the taxa involved in vivo were not clear $[78,79]$. We present the first

244 comprehensive study of human oxalate-degrading microbes, with multi-omics evidence, and 245 quantitatively characterized their contributions. Our finding that multiple human gut microbes 246 encode ODPs is consistent with multiple prior studies [22, 43, 64, 80, 81], but surprisingly, 247 oxalate degradation in the gut microbiome was dominated by a single organism - O. formigenes,

248 which is the only known oxalate-degrading specialist that exclusively uses oxalate as energy 249 and growth sources [22]. By actively transcribing ODPs, O. formigenes dominates the global 250 ODP of the microbiota, consistent with a previous proteomic analysis of $O$. formigenes cells, 251 showing FRC and OXC as the most abundant proteins produced during exponential and lag 252 stages [82]. 
253 Most kidney stones (85-90\%) are idiopathic with few genetic associations [83]. Here using the

254 risk population for nephrolithiasis - IBD patients as the surrogate, we provide novel insights that

255 the impaired metabolic activity of the microbiota may mediate enteric oxalate levels and

256 nephrolithiasis risk. We showed that fecal oxalate concentrations were elevated in the iHMP-

257 IBD UC patients, and CD patients with ileocolonic involvement, which is consistent with the 258 clinical observations of high $\mathrm{EH}$ risk $[73,84,85]$. EH may be an attractive indication for 259 microbiota-associated therapy, as the elevated soluble oxalate is in the intestine, providing an 260 advantage for oxalate degrading bacteria, such as 0 . formigenes to colonize and to be 261 metabolically active. Our finding that $O$. formigenes is less common in IBD patients than in 262 healthy individuals provides a rationale for restoring $O$. formigenes in this population. Previously O. formigenes-related therapeutics was only examined in patients with primary hyperoxaluria $264(\mathrm{PH})$ and yielded inconsistent results $[28,29,86,87]$. In contrast to $\mathrm{EH}, \mathrm{PH}$ is caused by high circulating oxalate of host origin, therefore $O$. formigenes-based therapy may be limited by oxalate secretion into the intestinal lumen $[31,88,89]$ for direct bacterial access.

267 The contrasting genetic and transcriptional changes in ODP observed in this study highlight the 268 importance of evidence beyond the gene level for microbiome studies. The integrative multi269 omics analysis framework built for this study, now deposited on Github, can also be extended to 270 a broad range of microbiome functions of interest, such as choline and tryptophan metabolism, 271 for example.

\section{Methods}

274 Meta-omics data of the human microbiome. Metagenomic and metatranscriptomic data of 275 healthy human subjects were collected from 5 studies and 4 studies, respectively[75, 90-95]. 276 Metagenomic and metatranscriptomic data of healthy humans and IBD subjects were collected 277 from the iHMP-IBD study [75]. Each sample was cleaned by KneaData to remove low-quality 
medRxiv preprint doi: https://doi.org/10.1101/2020.01.27.20018770; this version posted January 29, 2020. The copyright holder for this preprint (which was not certified by peer review) is the author/funder, who has granted medRxiv a license to display the preprint in perpetuity.

It is made available under a CC-BY-NC 4.0 International license .

278 reads and host-associated reads. The metabolic profiles of each sample were surveyed using

279 HUMAnN2 v0.11.1 [96] under parameters --prescreen-threshold 0.01, --pathways-database

280 metacyc_reactions_level4, metacyc_pathways_structured and --protein-database uniref50, for the

281 comparison in Fig. S2. Fecal oxalate concentration was determined from untargeted

282 metabolomics data from iHMP-IBD; measurements related to oxalate were selected for analysis.

283 Homologous proteins of ODE. The homologs protein families of OXDD, FRC, and OXC were

284 characterized by UniProt Interpro [59, 60] (V70) in protein families IPR017774, IPR017659, and

285 IPR017660, respectively. We acquired the taxonomic origin and amino acid sequences of 2,699

286 OXDD, 1,947 FRC, and 1,284 OXC homologs. Protein homologs that are 100\% identical were

287 then de-duplicated into 2519 OXDD, 1556 FRC, and 1037 OXC unique homologs, which were

288 used as a reference database of ODEs for a subsequent query against the meta'omics data.

289 Oxalate oxidoreductase (Fig. 1A), a recently discovered enzyme with limited information [51, 52,

290 97-101], was not considered in this present study.

291 Pairwise identity between ODE protein homologs. Multiple sequence alignments were

292 performed among the 2519 OXDD, $1556 \mathrm{FRC}$, and 1037 OXC unique protein homologs

293 separately, by muscle [102] in seaview v4.7 [103]. The alignments then were trimmed and

294 imported into R. The pairwise alignment distance $d$ was calculated using function dist.alignment

295 in the seqinR package [104] based on identity or Fitch matrix [105]. The alignment distance $d$

296 was subsequently converted to percent protein identity $100 *\left(1-d^{2}\right)$, following the

297 documentation of dist.alignment.

298 Detection of ODE in the meta'omics data. The quality-filtered meta'omics data were aligned

299 against the reference protein databases consisting of 2519 OXDD, 1556 FRC, and 1037 OXC

300 unique homologs, by diamond blastx [61], with best hit returned (--max-target-seqs 1).

301 Alignments with identity $>90 \%$ were kept for downstream analysis to achieve species-level

302 resolution for most taxa (Fig. S3) The abundance of each ODE protein homolog was calculated 
303 as reads per kilobase per million (RPKM) in each sample. When multiple timepoints were

304 available, each subject was represented by the mean measurements across all samples

305 provided.

306 Population-level contribution to ODE. The population-level contribution of a species to ODE

307 was designed as a measurement to take both prevalence and abundance information into 308 consideration. It is calculated for each ODE separately, based on their abundances (RPKM 309 values).

310 Using oxc as the example, suppose there are $M$ oxc-coding species and $N$ samples. In any 311 given sample $j$, the contribution of species $i$ to OXC, $c_{i j}$, is represented by its relative oxc 312 abundance, calculated from

$$
c_{i j}=z_{i j} / \sum_{i=1}^{M} z_{i j}
$$

313 where the $z_{i j}$ denotes the RPKM oxc of species $i$ in sample $j$. In this way, we normalize across 314 samples with the total contribution in any OXC-positive samples is fixed to 1 , in any OXC315 negative samples is 0 .

316 The population-level contribution of species $i: C_{i}$, can be subsequently calculated from 317 summating contribution of species $i$ in $N$ samples, as follows

$$
C_{i}=\sum_{j=1}^{N} c_{i j}
$$

318 Note that population-level contribution of species monotonically increases with sample size $N$.

319 Therefore, it is transformed to relative scale when being compared across different populations 320 or different sample types (metagenome vs. metatranscriptome), such as in Fig. 3C, Fig. S8, 321 and 12. 
322 Network analysis. A network analysis on oxc or frc expression from microbial species using

323 SpiecEasi[106]. The raw RPKM values were used and the networks were constructed under

324 default parameter method='mb', sel.criterion='bstars', lambda.min.ratio=2e-2,nlambda=100,

325 pulsar.params=list(rep.num=20, ncores $=2)$.

326 Code availability. Source code of the pipeline can be found on Github via 327 https://github.com/ml3958/FindTaxaCtrbt. Downstream analyses scripts are available per 328 request.

\section{Acknowledgements}

331 We thank Dr. David Goldfarb, Dr. David Fenyo, Dr. Victor Torres, Dr. Joao Xavier and Xuhui 332 Zheng for their helpful comments. This study was supported in part by U01Al22285, 333 R01DK110014, and the Rare Kidney Stone Consortium (U54 DK083908) from the National 334 Institutes of Health, by the C \& D and Zlinkoff Funds, Oxalosis and Hyperoxaluria Foundation335 American Society of Nephrology career development grant, and the TransAtlantic Partnership of 336 the Fondation LeDucq.

\section{Contributions}

338 M.L, L.N, and M.J.B designed the study and wrote the manuscript. M.L, J.C.D, J.H performed 339 the analyses. M.L, J.C.D, A.V, T.B collected the data. A.B, P.L, H.L, K.V.R, A.T contributed by 340 suggesting additional new analysis and associated methods.

\section{Competing interests}

343 A.L.B is an employee of Genentech. The remaining authors have no competing interest. 
medRxiv preprint doi: https://doi.org/10.1101/2020.01.27.20018770; this version posted January 29, 2020. The copyright holder for this preprint (which was not certified by peer review) is the author/funder, who has granted medRxiv a license to display the preprint in perpetuity. 
medRxiv preprint doi: https://doi.org/10.1101/2020.01.27.20018770; this version posted January 29, 2020. The copyright holder for this preprint (which was not certified by peer review) is the author/funder, who has granted medRxiv a license to display the preprint in perpetuity.

It is made available under a CC-BY-NC 4.0 International license .

\section{Figures}

347 Figure 1.

\section{A}

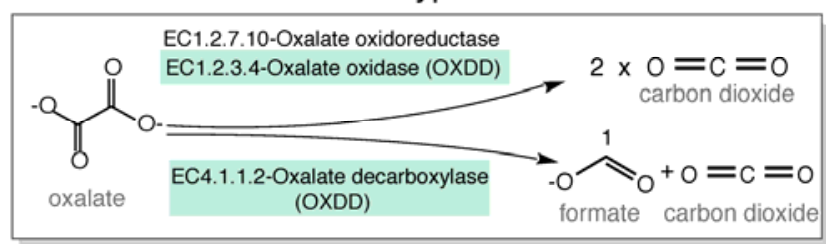

353

354

355

356

357

358

359

360

361

362

363

364

365

366

367 368 FRC, and OXC are the focus of the present study.
B

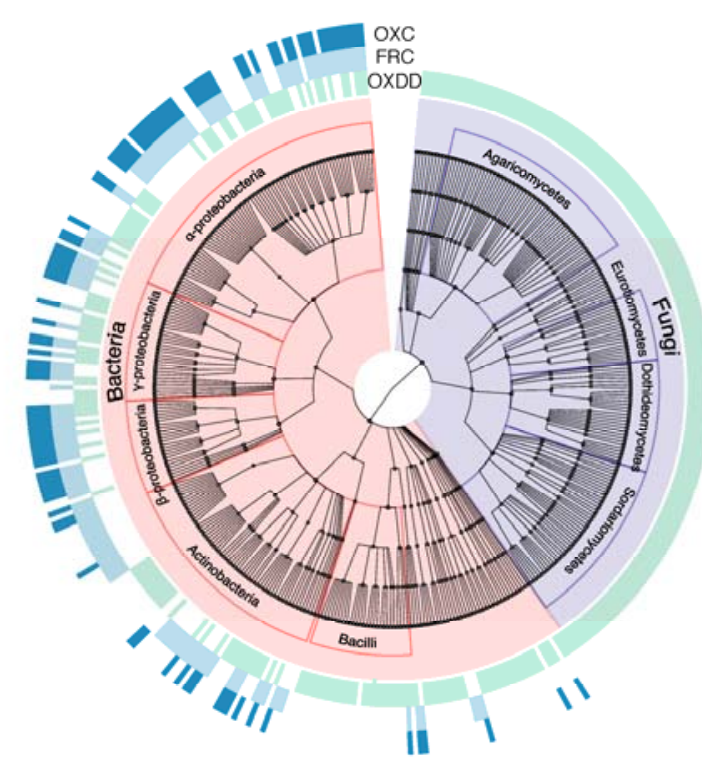

Figure 1. Type I and type II microbial oxalate-degrading pathway (ODP).

(A). Schema of type I and type II ODP. Enzymes are annotated with corresponding KEGG IDs. OXDD,

(B). Cladogram of microbial genera that encode oxalate-degrading enzymes OXDD, FRC, and OXC. The three rings surrounding the cladogram indicate OXDD-, FRC- or OXC-encoding genera, respectively. 
Figure 2.

A
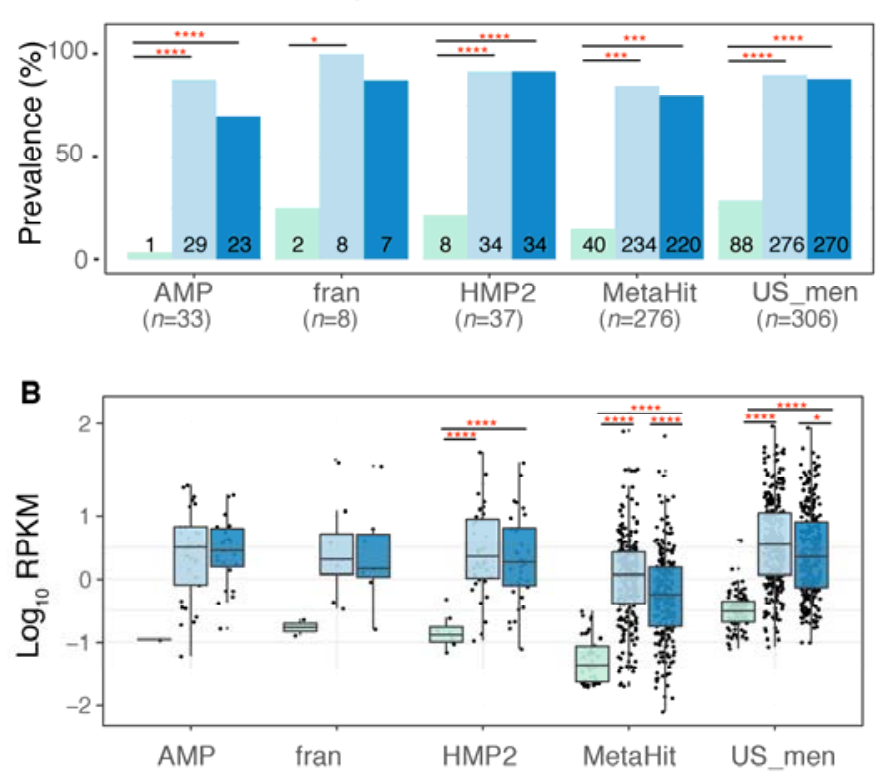

C Metatranscriptome ( $n=165$ subjects)
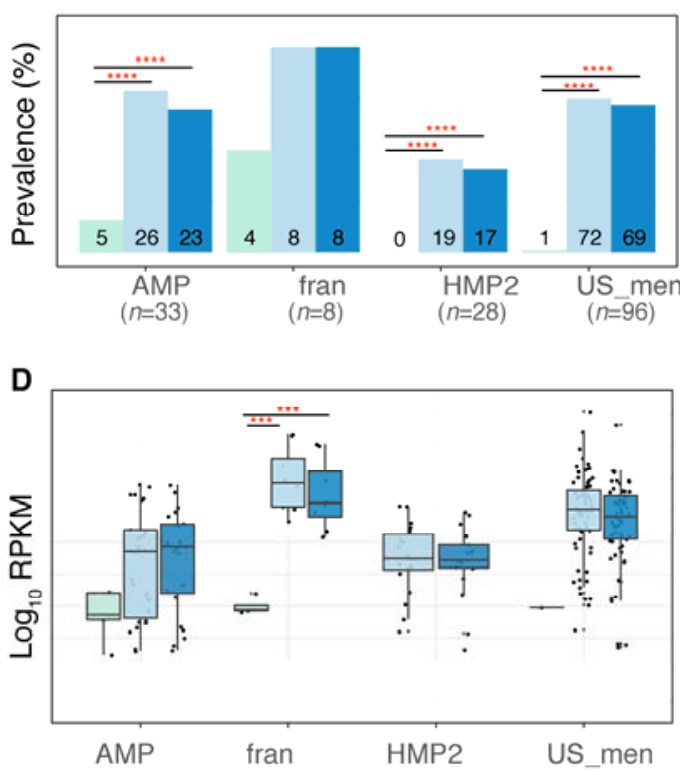

Figure 2. Detection of type I and II ODE within the fecal metagenome and metatranscriptome of 660 and 165 healthy human subjects.

Prevalence $(A)$ and abundance $(B)$ of ODE in the fecal metagenome of five studies surveyed.

Numbers written on the bottom bars indicate the numbers of subjects in whom the corresponding ODE is studies surveyed.

${ }^{*}: p<0.05,{ }^{* *}: p<0.01,{ }^{* * *}: p<0.001,{ }^{* * * *}: p<0.0001$, by proportion tests for panels $A$ and $C$, by multiple- 
medRxiv preprint doi: https://doi.org/10.1101/2020.01.27.20018770; this version posted January 29, 2020. The copyright holder for this preprint (which was not certified by peer review) is the author/funder, who has granted medRxiv a license to display the preprint in perpetuity.

It is made available under a CC-BY-NC 4.0 International license .

Figure 3.
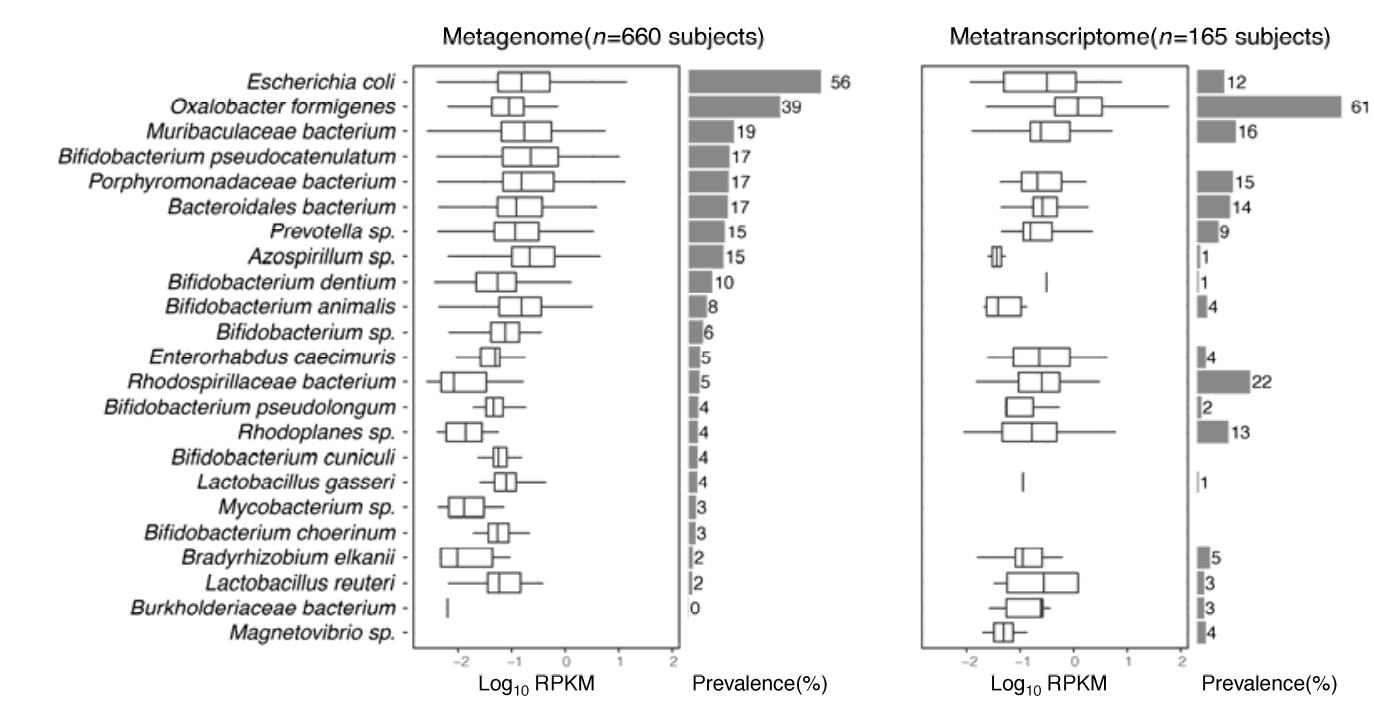
humans.
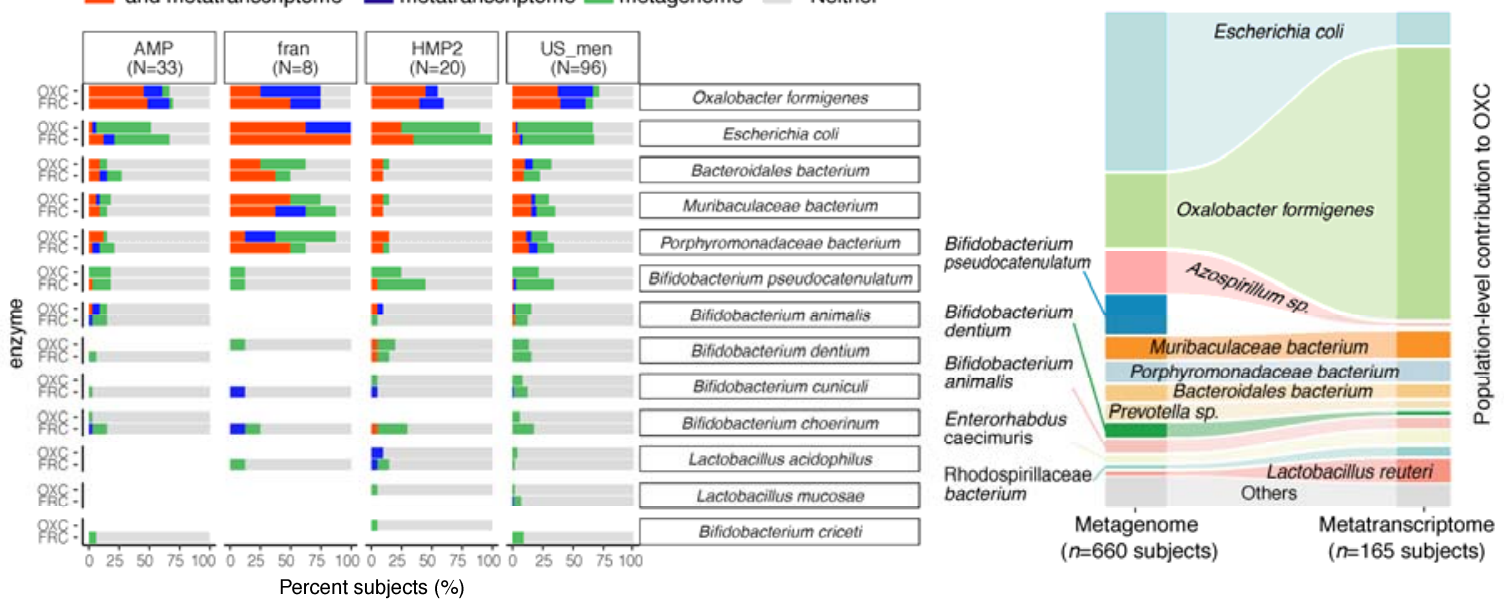

(A) Abundance and prevalence of OXC of microbial species in the metagenome (left) or metatranscriptome (right) of 660 and 165 subjects. Box plots indicate the abundance of microbial OXC $\left(\log _{10}\right.$ RPKM) among subjects in whom OXC is detected, and are generated with ggplot2 with outliers excluded. Bar plots indicate the prevalence of microbial oxc, with percentage annotated. Microbial species are ordered by the corresponding metagenomic OXC prevalence. A parallel analysis for FRC is shown in Suppl. Fig 5.

(B) Detection of OXC and FRC of microbial species in the subject-matched metagenome and metatranscriptome, by study. For each microbial ODE, the subjects are divided into four groups (shown in different colors) based on the co-detection of ODE in the matched metagenome and metatranscriptome, with percent (\%) of which reflected. The fran Study, from which E. coli ODP was detected in all subjects, used a sample extraction method known to induce E. coli, as noted in their publication [92].

\section{(C). Population-level contribution of individual species to metagenomic (left) or} metatranscriptomic (right) OXC. The population level-contribution of each species was calculated at a relative scale (see Methods) and plotted. Raw values can be found in Suppl. Table 1. The 10 species that 
medRxiv preprint doi: https://doi.org/10.1101/2020.01.27.20018770; this version posted January 29, 2020. The copyright holder for this preprint (which was not certified by peer review) is the author/funder, who has granted medRxiv a license to display the preprint in perpetuity. It is made available under a CC-BY-NC 4.0 International license.

438 have the highest metagenomic or metatranscriptomic contribution are shown. A parallel analysis for FRC 439 is shown in Suppl. Fig. 7. 
medRxiv preprint doi: https://doi.org/10.1101/2020.01.27.20018770; this version posted January 29, 2020. The copyright holder for this preprint (which was not certified by peer review) is the author/funder, who has granted medRxiv a license to display the preprint in perpetuity.

It is made available under a CC-BY-NC 4.0 International license .

Figure 4.
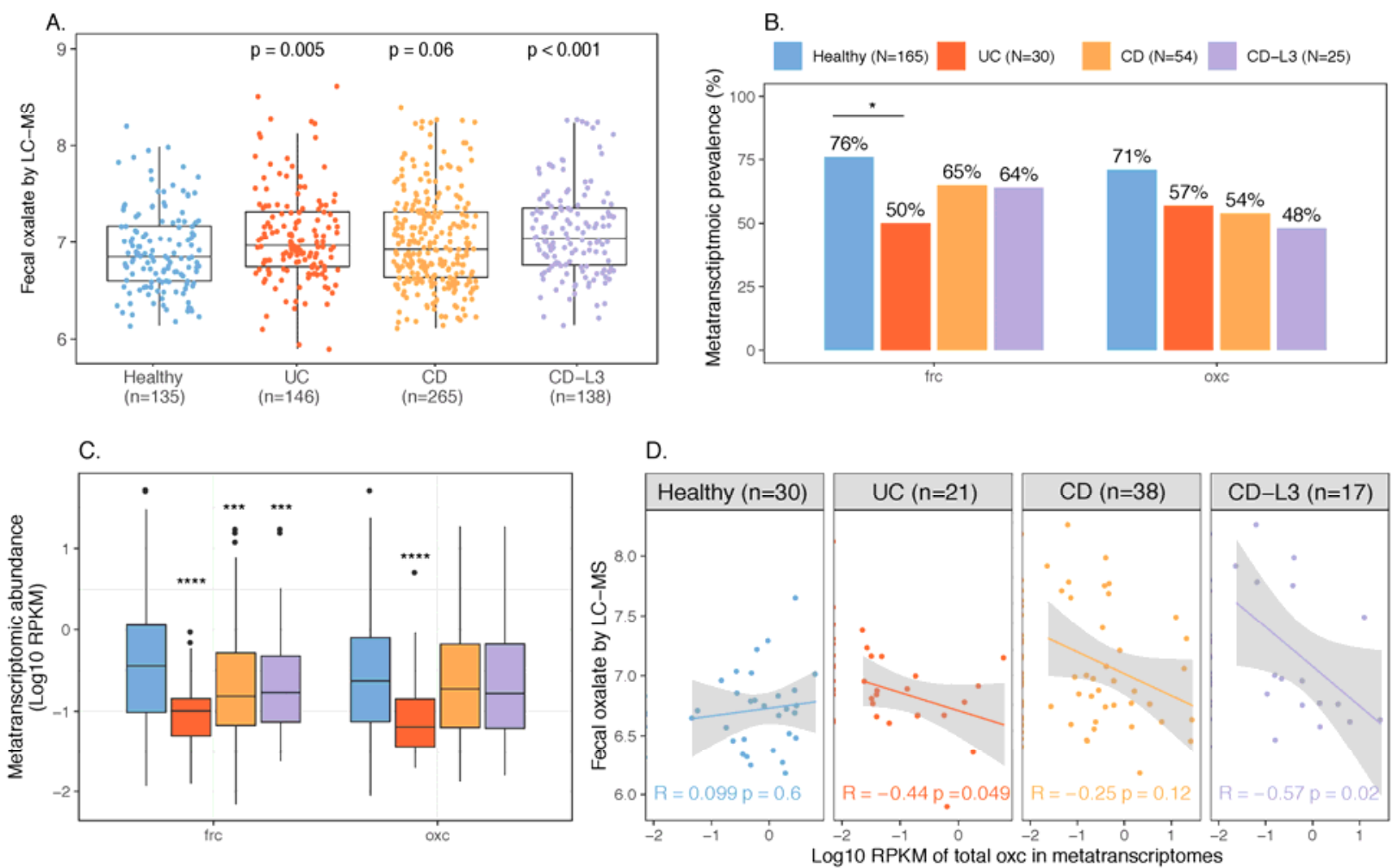

Figure 4. Elevated fecal oxalate concentrations and reduced expression of microbiome ODP in 446 IBD patients.

(A). Stool oxalate concentrations in healthy, UC, CD, or CD-L3 subjects from HMP-IBD study. L3 refers to the ileocolonic phenotype, according to the Montreal Classification) at baseline. Data derived from iHMP-IBD untargeted metabolomics measurements.

Prevalence (B) and abundance (C) of OXDD, FRC, and OXC in metatranscriptomes of healthy, UC, CD, or CD-L3 subjects. The 165 healthy controls are combined from four studies (AMP, US_men, fran, HMP2). ${ }^{*}: p<0.05,{ }^{* *}: p<0.01,{ }^{* * *}: p<0.001,{ }^{* * * *}: p<0.0001$ by multiple-adjusted Mann-Whitney tests in $A$ and $C$, by proportion test in B. (D). Spearman correlations of fecal oxalate and total metatranscriptomic 
medRxiv preprint doi: https://doi.org/10.1101/2020.01.27.20018770; this version posted January 29, 2020. The copyright holder for this preprint (which was not certified by peer review) is the author/funder, who has granted medRxiv a license to display the preprint in perpetuity.

It is made available under a CC-BY-NC 4.0 International license.

Figure 5. IBD patients

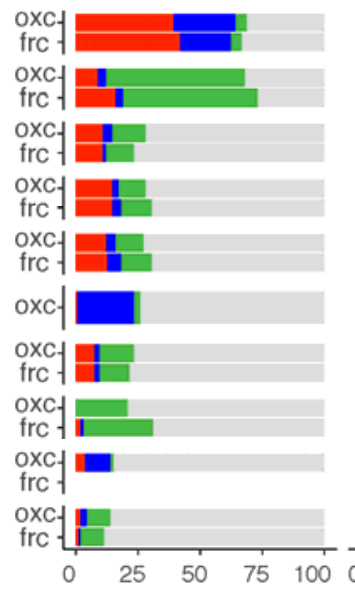

$$
\text { UC ( } n=22 \text { subjects) }
$$

CD ( $n=45$ subjects)

CD-L3 ( $n=20$ subjects)

Figure 5. Differential ODP expression by human gut microbes in healthy and disease states.

\section{(A) Detection of microbial OXC and FRC in the subject-matched metagenome and} metatranscriptome from healthy subjects, UC, CD, or CD-L3 patients. For each species shown, the subjects are divided into one of four categories based on the co-detection of ODE in the matched metagenome and metatranscriptome.

488

(B) Expression of microbial FRC and OXC in the metatranscriptomes of healthy subjects, UC, CD, or CD-L3 patients. Boxplot reflects the subjects, in whose metatranscriptome the corresponding enzyme 
medRxiv preprint doi: https://doi.org/10.1101/2020.01.27.20018770; this version posted January 29, 2020. The copyright holder for this preprint (which was not certified by peer review) is the author/funder, who has granted medRxiv a license to display the preprint in perpetuity.

It is made available under a CC-BY-NC 4.0 International license .

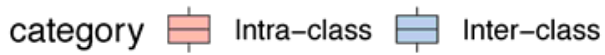

\section{A. OXDD}

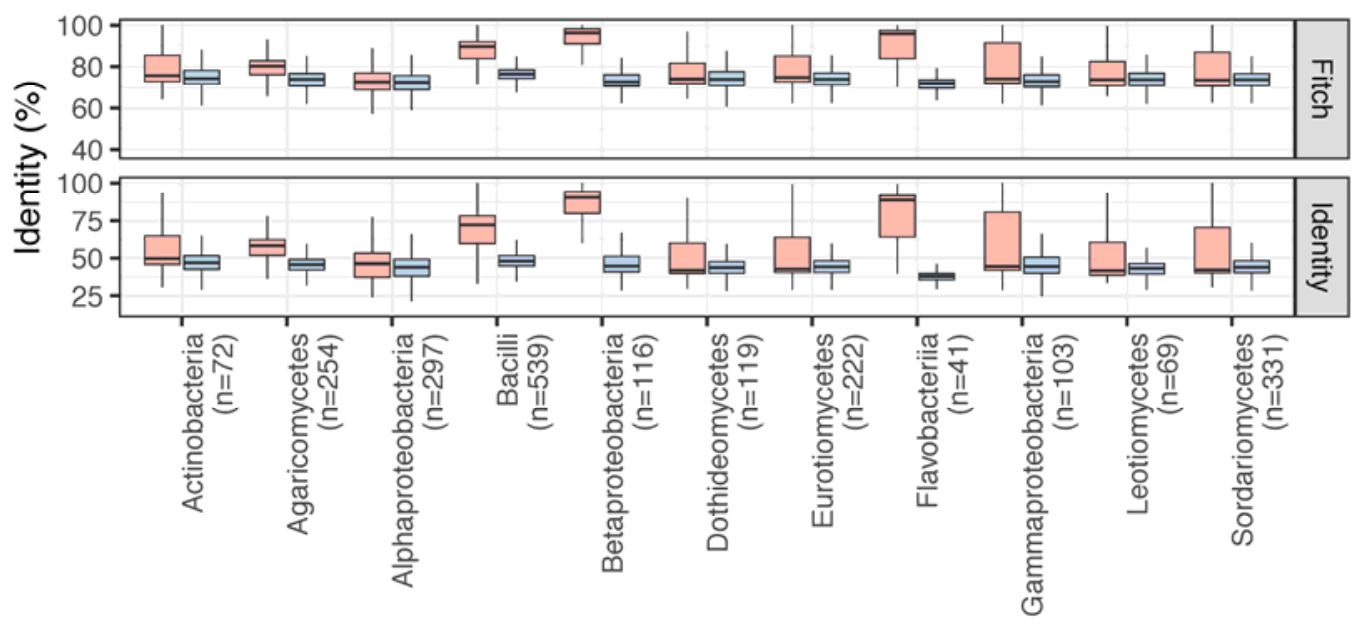

B. OXC

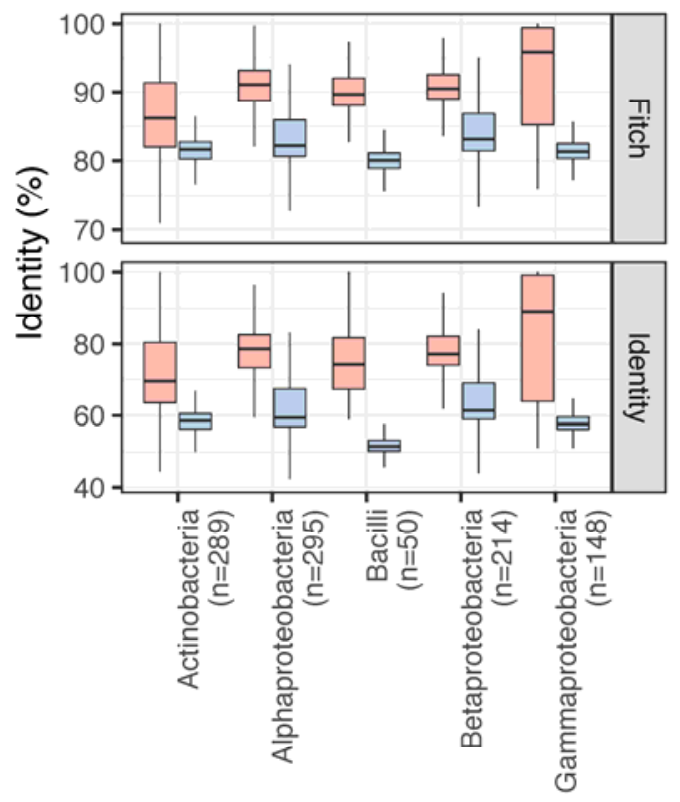

C. FRC

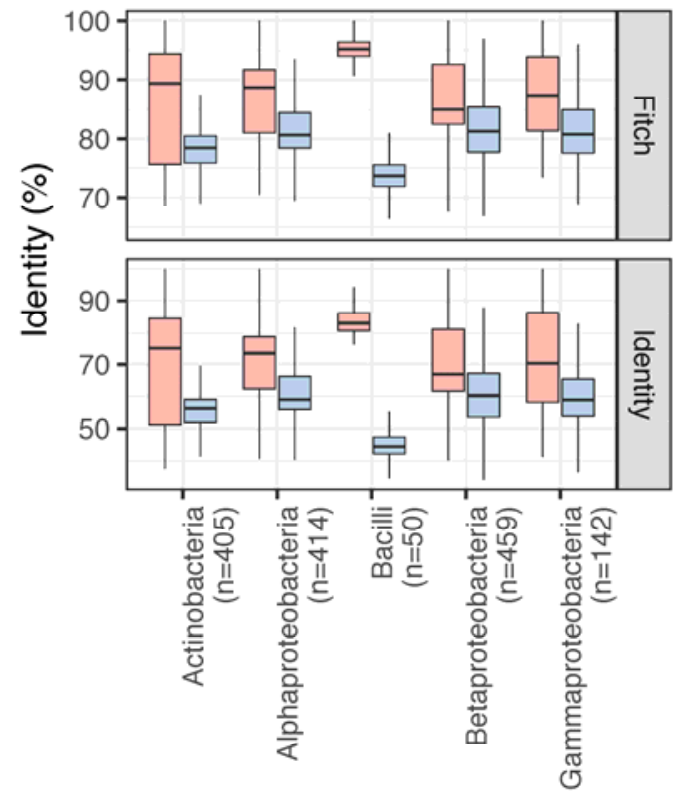

493

494

495

496

497

498
Figure S1. Inter-class and intra-class ODE protein identity associated with each microbial class. Panels focus on OXDD (A), OXC (B), or FRC (C). The pairwise identity between any two protein homologs was calculated based on the multiple alignments using amino acid sequences, by Fitch [105] or identity distance matrix (See Methods for details). The number of ODE homologs available for each class is indicated in parenthesis. Classes with $>20$ ODE are shown. 
medRxiv preprint doi: https://doi.org/10.1101/2020.01.27.20018770; this version posted January 29, 2020. The copyright holder for this preprint (which was not certified by peer review) is the author/funder, who has granted medRxiv a license to display the preprint in perpetuity. It is made available under a CC-BY-NC 4.0 International license .

500

501
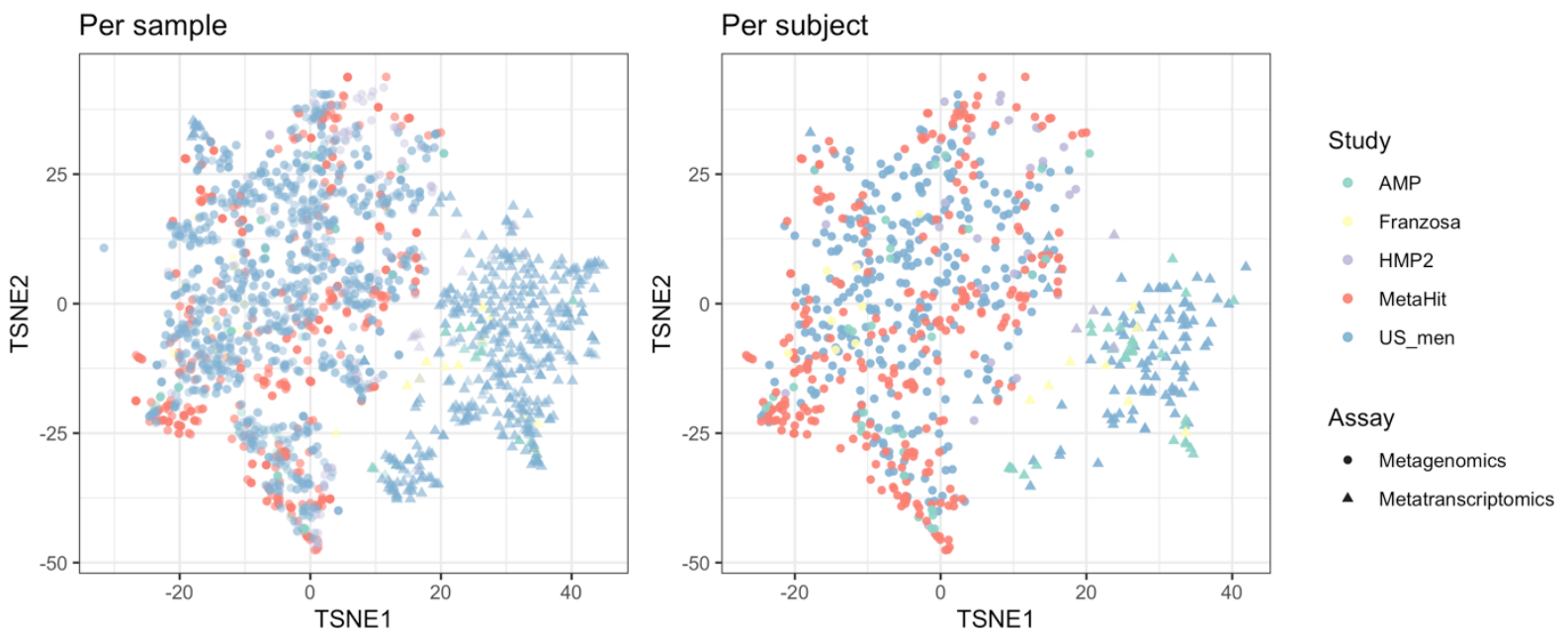

Figure S2. Beta-diversity of metabolic profiles associated with the metagenomic and metatranscriptomic samples from healthy human subjects, ordinated on a Tsne (t-distributed stochastic neighbor embedding) plot. The metabolic profile is assessed by the HUMAnN2 [96] pipeline using (see Methods). The metabolic profiles for each subject are calculated by taking the mean

508 measurements provided. The table shows the number of subjects who provided metagenomic (MTG •) 
medRxiv preprint doi: https://doi.org/10.1101/2020.01.27.20018770; this version posted January 29, 2020. The copyright holder for this preprint (which was not certified by peer review) is the author/funder, who has granted medRxiv a license to display the preprint in perpetuity.

It is made available under a CC-BY-NC 4.0 International license .

Figure S3.

category 官 Inter-species 官 Intra-species

\section{A. OXDD}

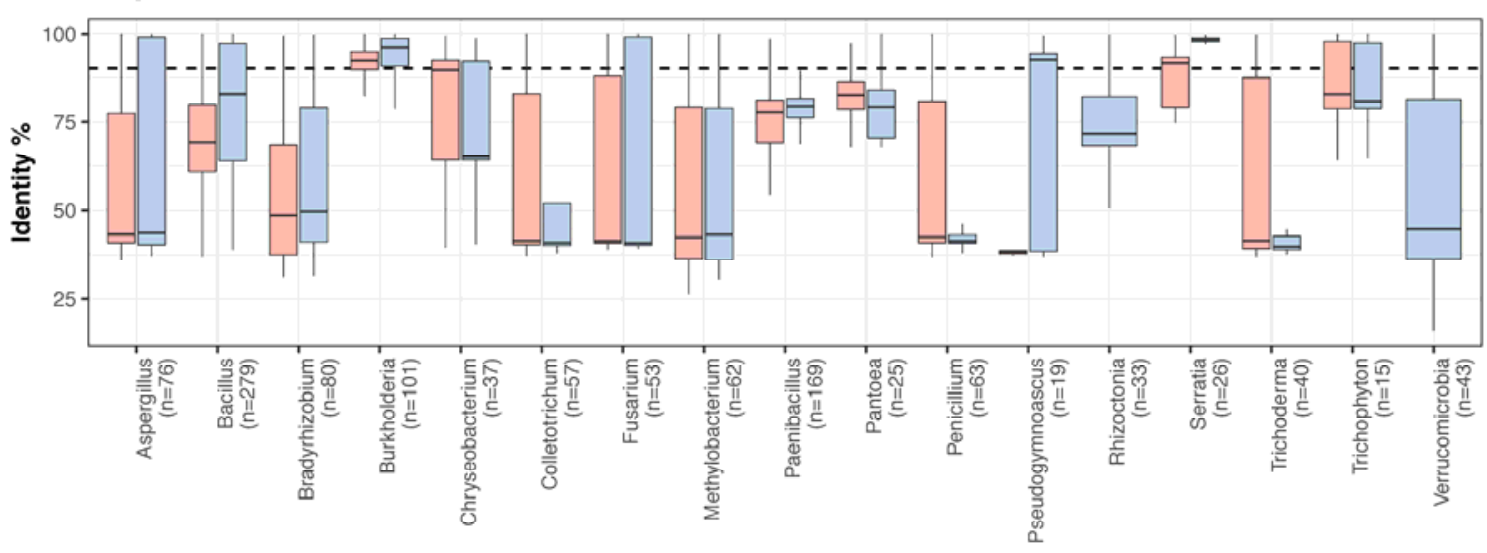

B. OXC

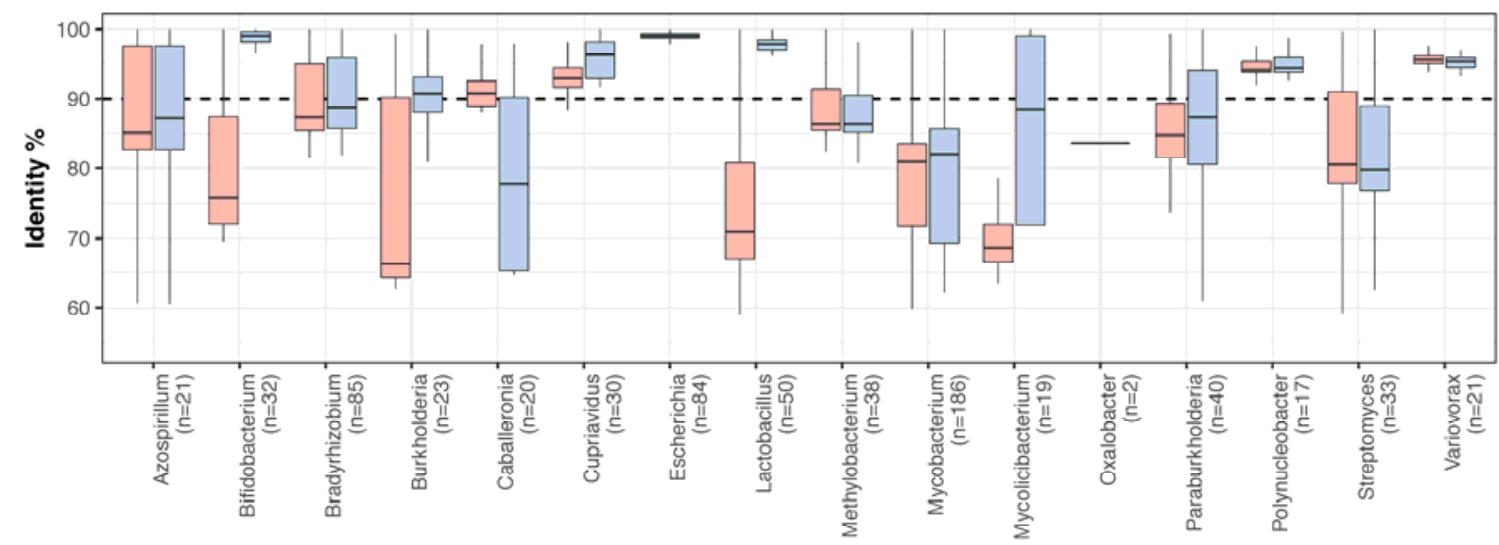

C. FRC

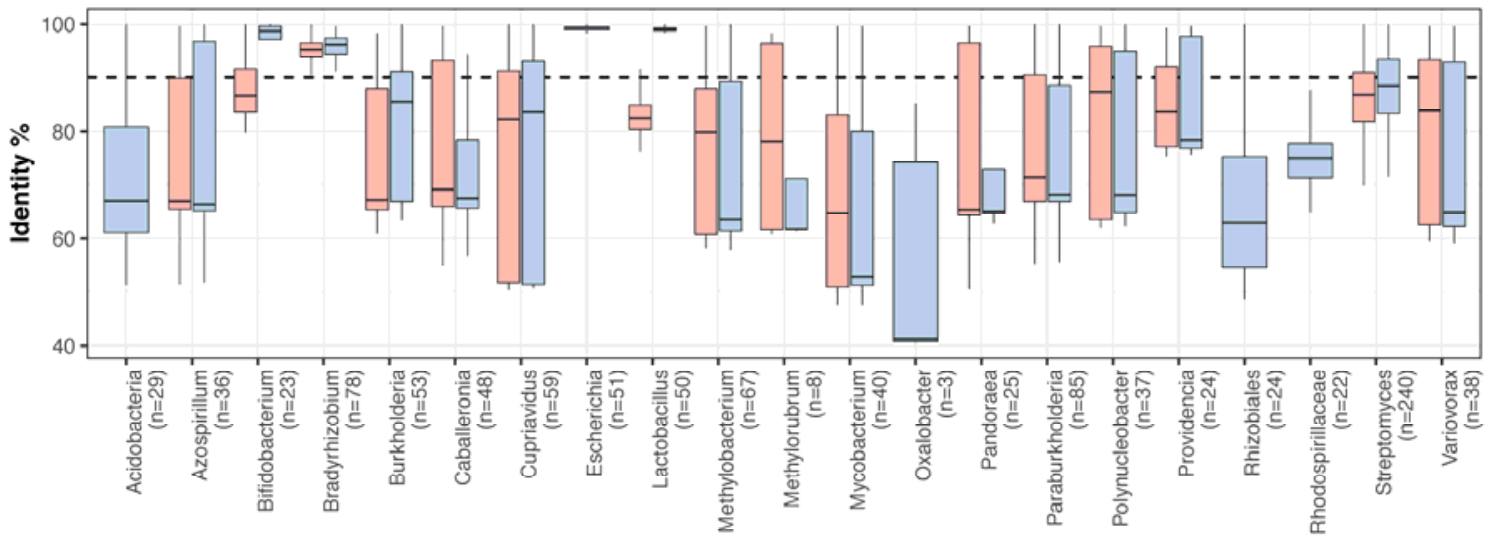
genus. Panels focus on $\operatorname{OXDD}(A), \operatorname{OXC}(B)$, or FRC (C). The pairwise protein identities were calculated based on amino acid sequence alignment (See Methods for details). The number of ODE homologs available for each genus is indicated in parenthesis. The blastx identity cutoff $90 \%$ used in this study is indicated by the dashed line. Genera with >20 ODE homologs and Genus Oxalobacter are shown. 
medRxiv preprint doi: https://doi.org/10.1101/2020.01.27.20018770; this version posted January 29, 2020. The copyright holder for this preprint (which was not certified by peer review) is the author/funder, who has granted medRxiv a license to display the preprint in perpetuity. It is made available under a CC-BY-NC 4.0 International license .

\section{Figure S4}

519

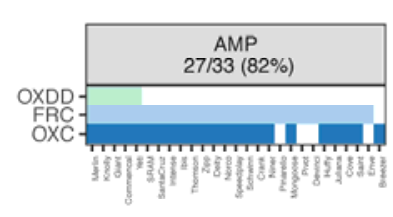

\begin{tabular}{|c|c|}
\hline $\begin{array}{c}\text { fran } \\
8 / 8(100 \%)\end{array}$ \\
\hline \\
\hline
\end{tabular}

$$
\text { enzyme } \square \text { OxDD } \square \text { FRC } \square \text { oxc }
$$

521 Figure S4. Co-detection of OXDD, FRC, and OXC in the metatranscriptomes of subjects across 522 different studies. Subjects with at least one ODE detected in the metatranscriptome are shown, with 523 percent of total subjects displayed in panels, for each study, indicated in parentheses. 
medRxiv preprint doi: https://doi.org/10.1101/2020.01.27.20018770; this version posted January 29, 2020. The copyright holder for this preprint (which was not certified by peer review) is the author/funder, who has granted medRxiv a license to display the preprint in perpetuity.

It is made available under a CC-BY-NC 4.0 International license .

\section{Figure S5}

Metagenome( $n=306$ subjects $)$
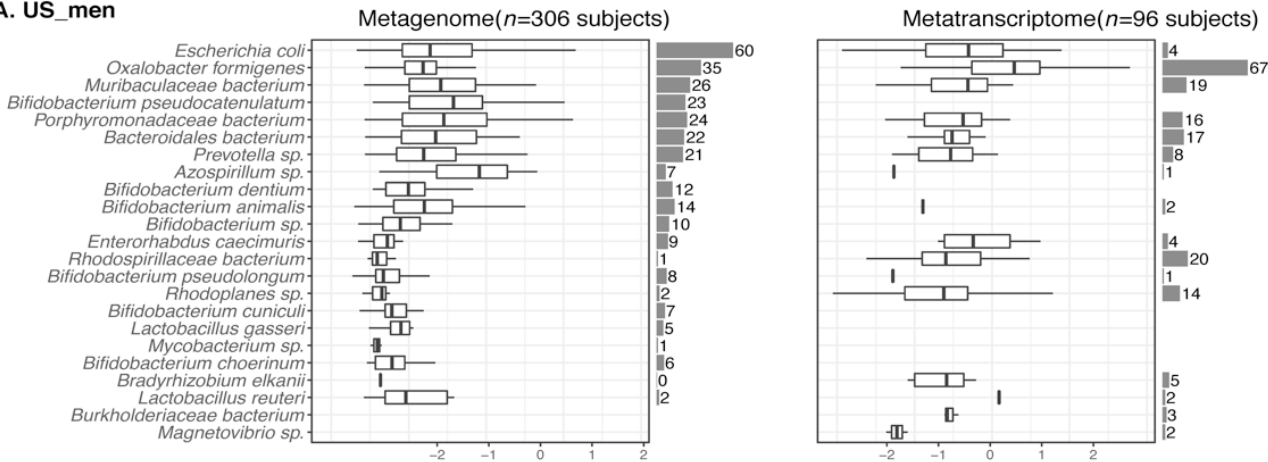

B. HMP2
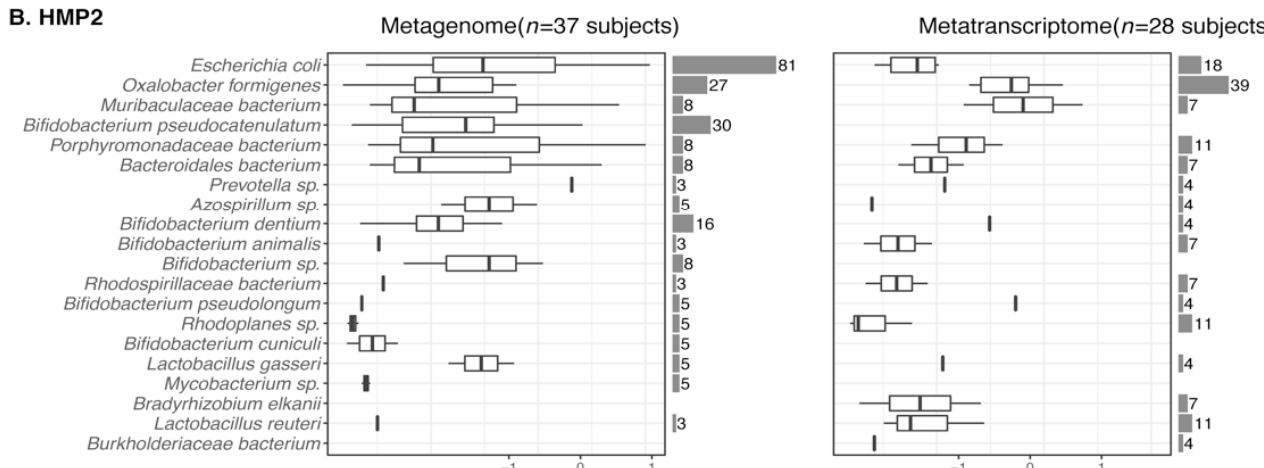

541

C. AMP

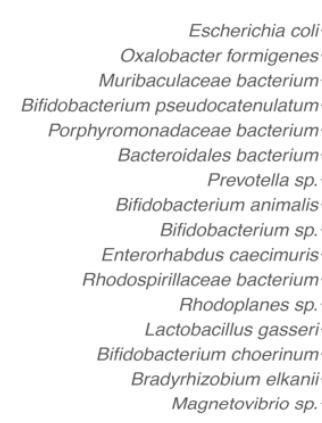

Metagenome $(n=33$ subjects $)$

D. fran Metagenome( $n=8$ subjects)
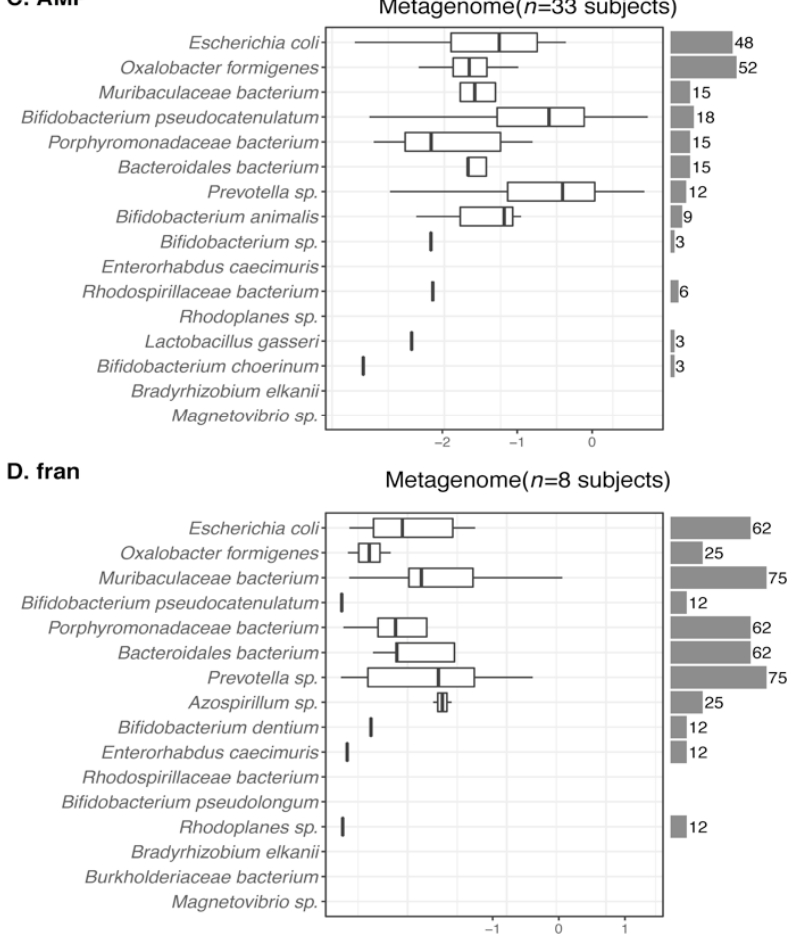

Log 10 RPKM

Prevalence(\%)
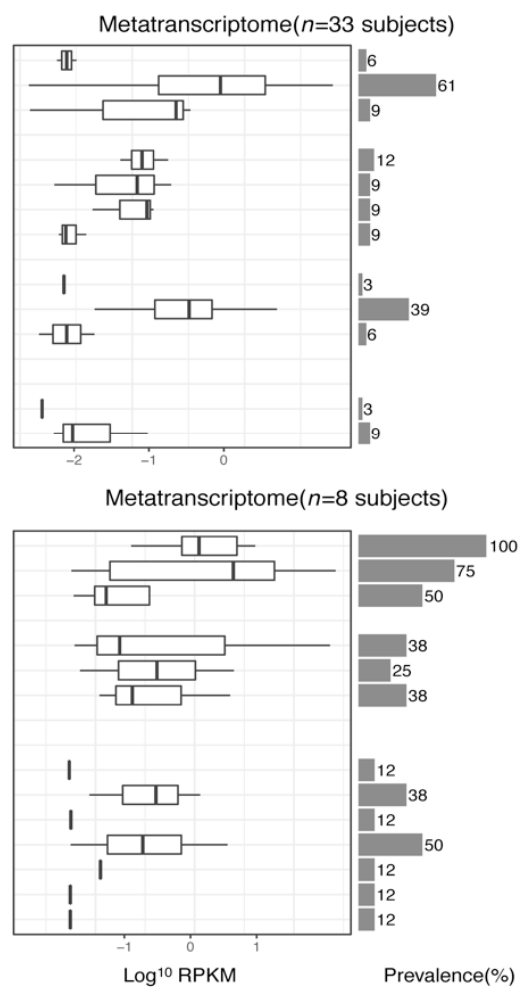
metagenomic and metatranscriptomic data, respectively. (Follows legend of Fig. 3A). 
medRxiv preprint doi: https://doi.org/10.1101/2020.01.27.20018770; this version posted January 29, 2020. The copyright holder for this preprint (which was not certified by peer review) is the author/funder, who has granted medRxiv a license to display the preprint in perpetuity. It is made available under a CC-BY-NC 4.0 International license.

\section{Figure S6}

563
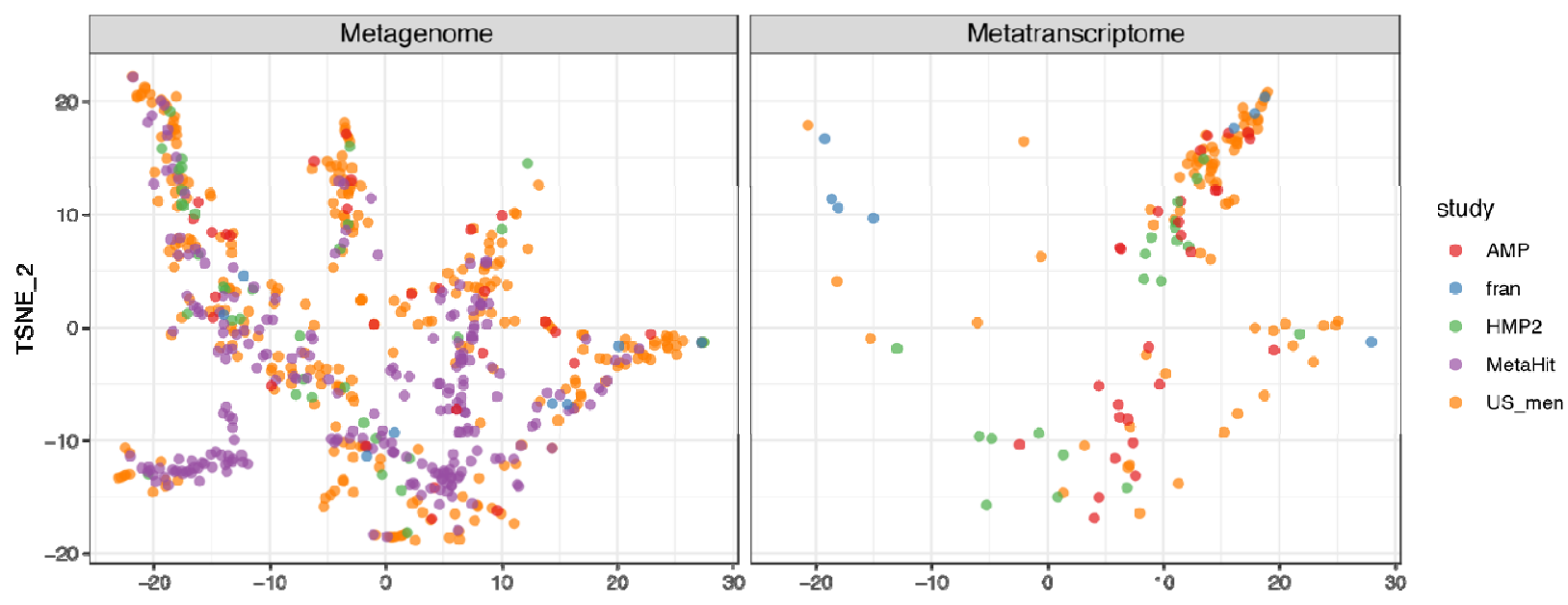

565

Figure S6. Tsne plot of 594 metagenomic and 131 metatranscriptomic samples, based on the abundances OXC and FRC. OXC and FRC of microbes in Figures 3A and S5 were used. Tsne is calculated with Rtsne v0.15 package in R. The OXC- and FRC- specific study effects are not significant, examined using PERMANOVA using 1000 permutations $(p>0.1)$. 
medRxiv preprint doi: https://doi.org/10.1101/2020.01.27.20018770; this version posted January 29, 2020. The copyright holder for this preprint (which was not certified by peer review) is the author/funder, who has granted medRxiv a license to display the preprint in perpetuity. It is made available under a CC-BY-NC 4.0 International license.

\section{Figure S7}

572 (right) of healthy human subjects. (Follows the legend of Fig. 3A). 
medRxiv preprint doi: https://doi.org/10.1101/2020.01.27.20018770; this version posted January 29, 2020. The copyright holder for this preprint (which was not certified by peer review) is the author/funder, who has granted medRxiv a license to display the preprint in perpetuity. It is made available under a CC-BY-NC 4.0 International license.

\section{Figure S8}

583

584

585

586

587

588

589

590

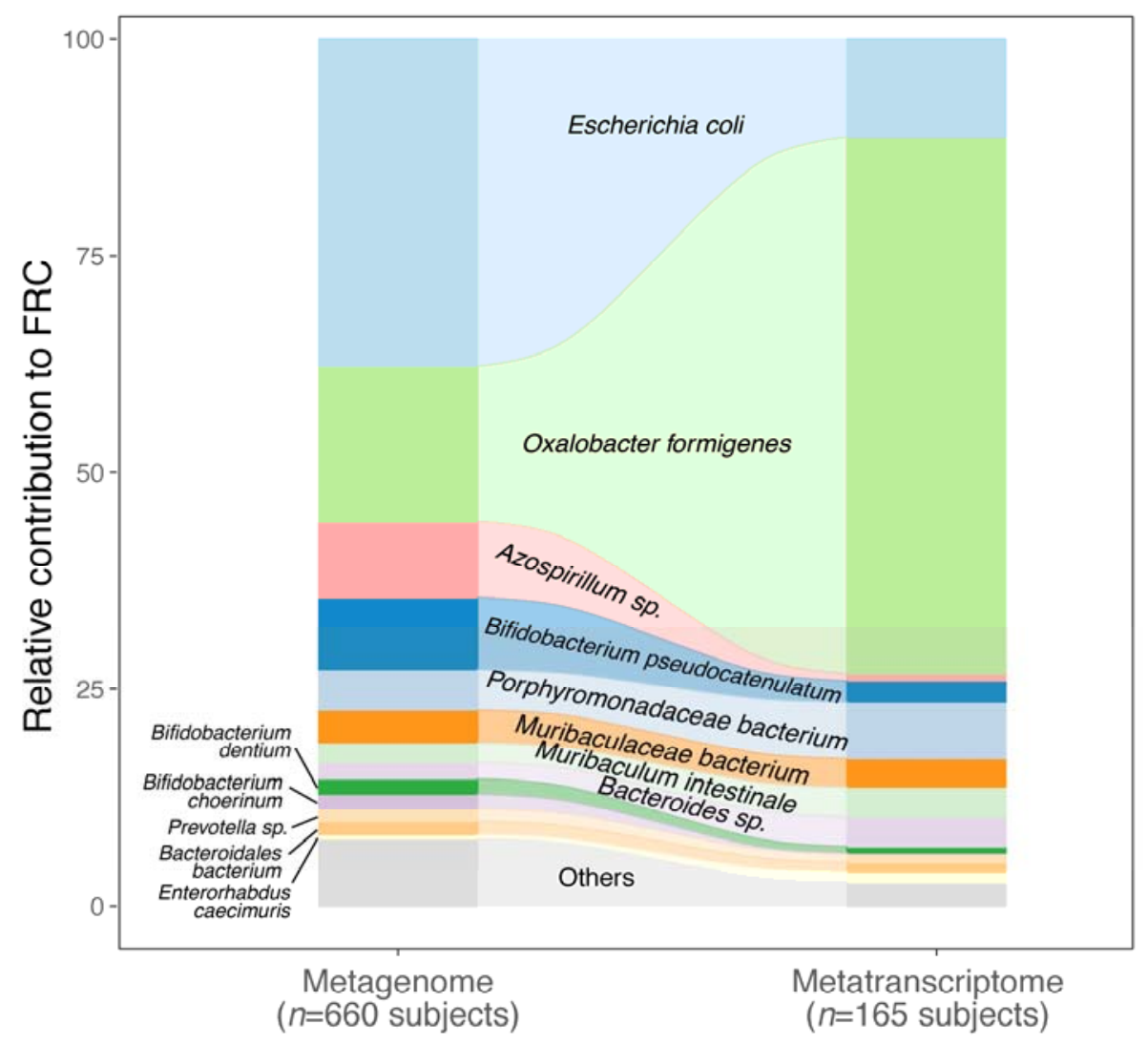
metatranscriptomic (right) FRC. Follows the legend of Fig. 3D.

603

604 
medRxiv preprint doi: https://doi.org/10.1101/2020.01.27.20018770; this version posted January 29, 2020. The copyright holder for this preprint (which was not certified by peer review) is the author/funder, who has granted medRxiv a license to display the preprint in perpetuity.

It is made available under a CC-BY-NC 4.0 International license .

\section{Figure S9}

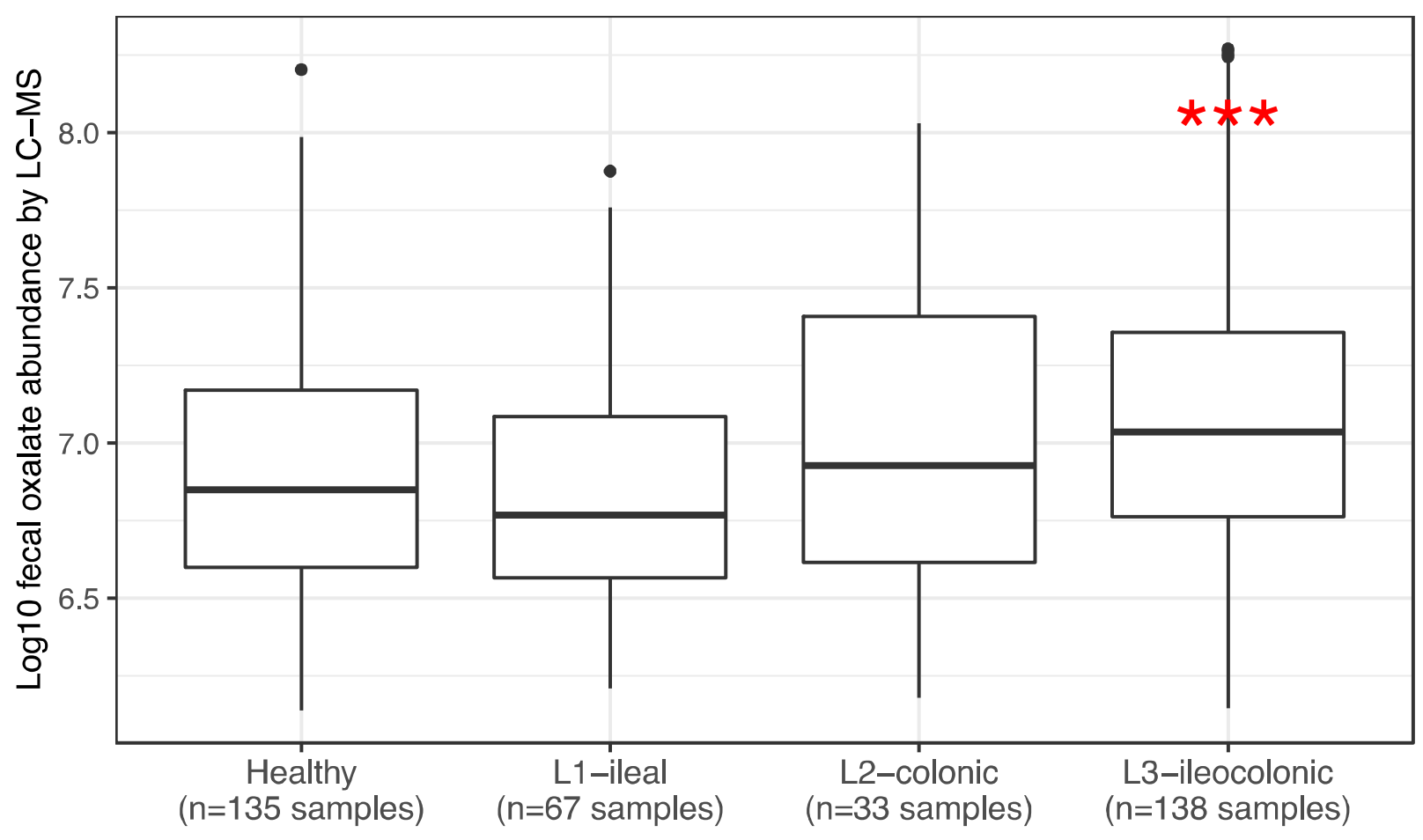

Figure S9. Fecal oxalate concentrations in CD patients, according to the Montreal clinical classification. 
medRxiv preprint doi: https://doi.org/10.1101/2020.01.27.20018770; this version posted January 29, 2020. The copyright holder for this preprint (which was not certified by peer review) is the author/funder, who has granted medRxiv a license to display the preprint in perpetuity.

It is made available under a CC-BY-NC 4.0 International license .

\section{A}

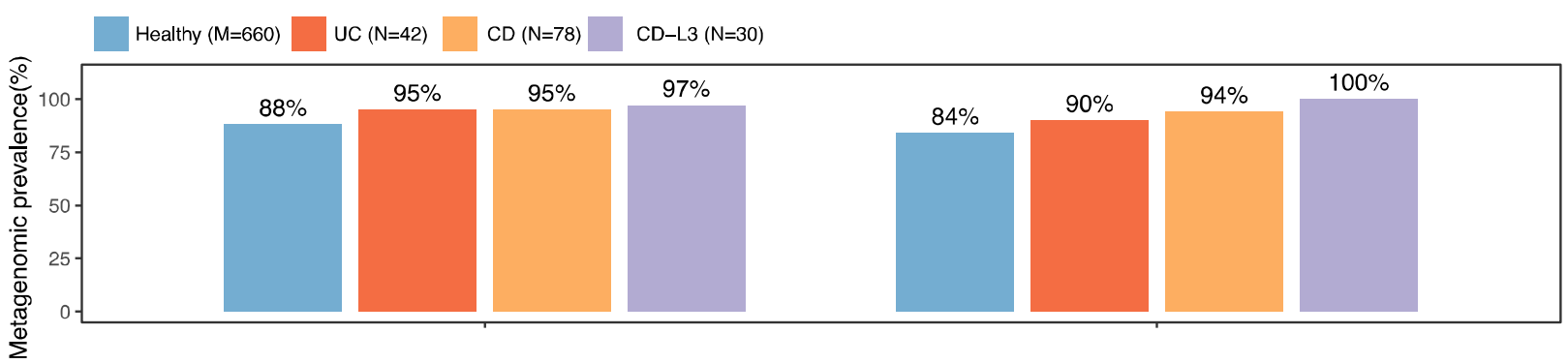

614

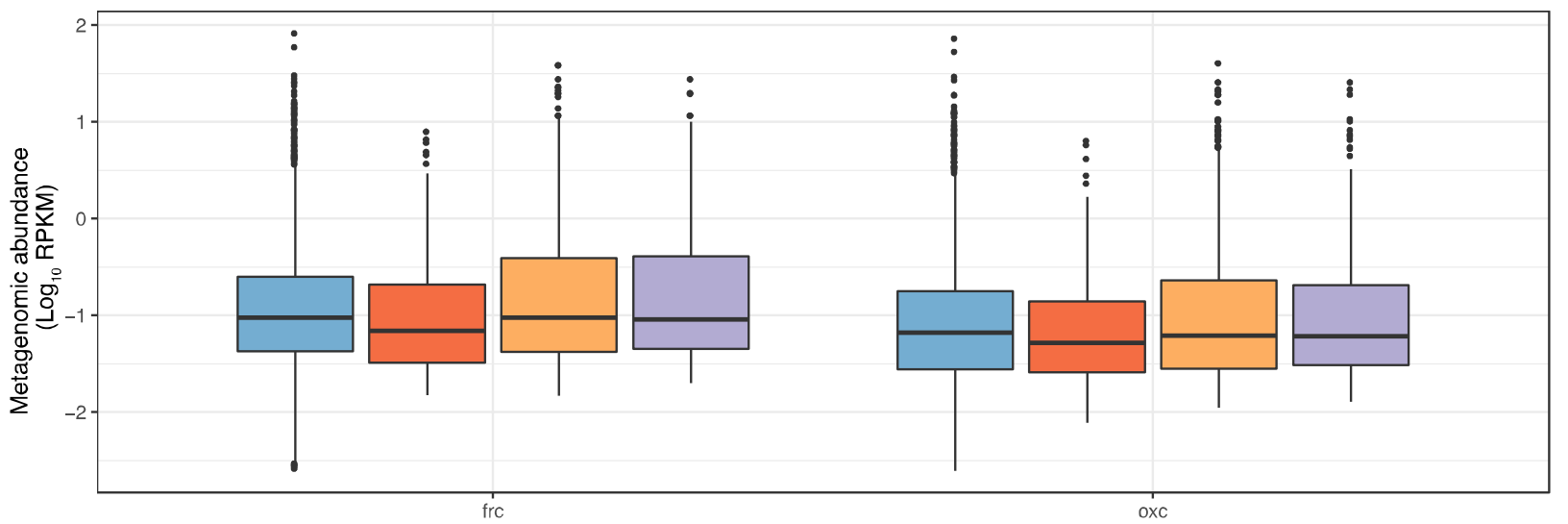

615 B
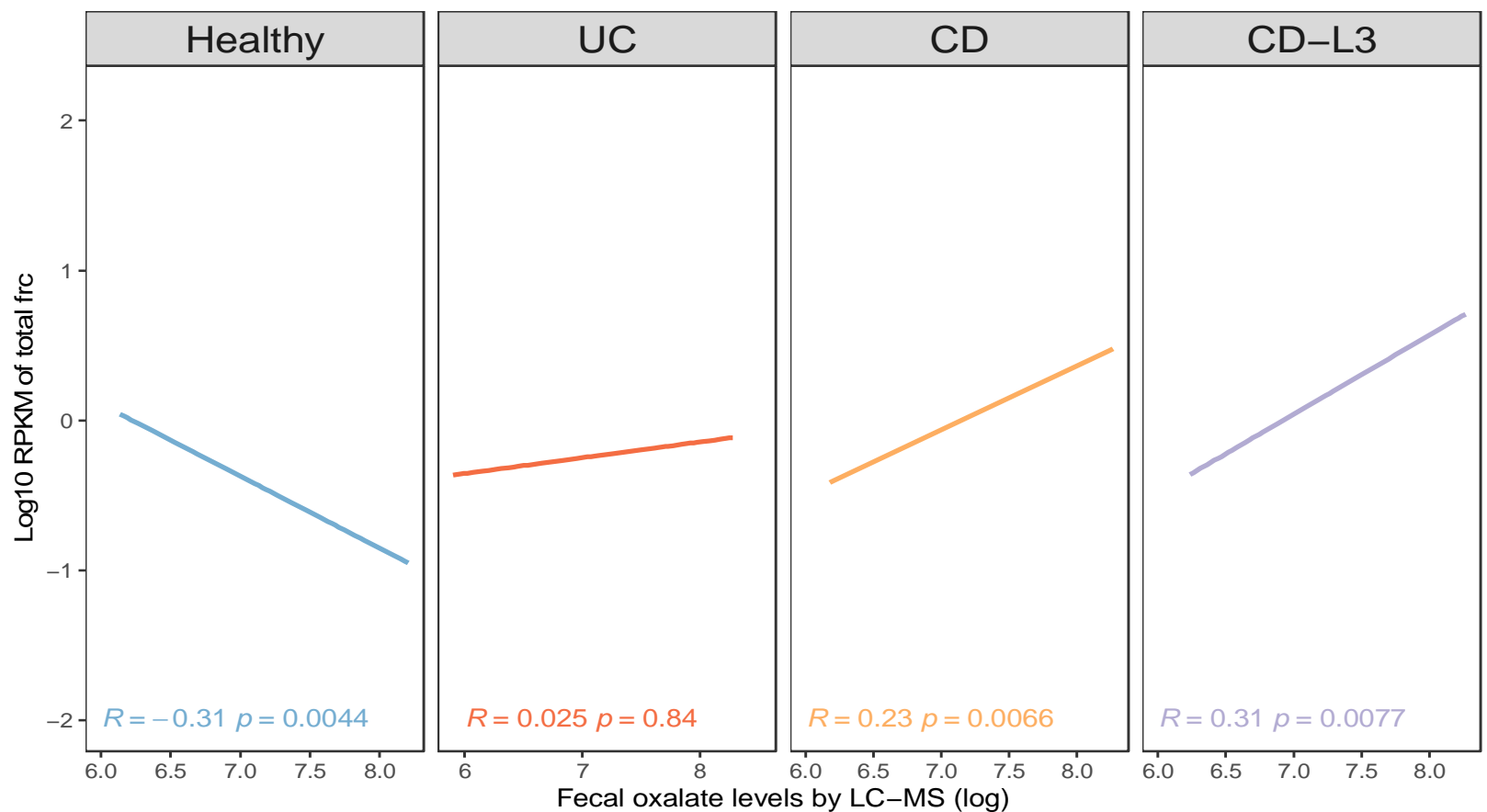

Figure S10. (A) Metagenomic prevalence (top) and abundance (bottom) of frc and oxc in healthy, UC, 
medRxiv preprint doi: https://doi.org/10.1101/2020.01.27.20018770; this version posted January 29, 2020. The copyright holder for this preprint (which was not certified by peer review) is the author/funder, who has granted medRxiv a license to display the preprint in perpetuity.

It is made available under a CC-BY-NC 4.0 International license .

\section{References}

622

623

624

625

626

627

628

629

630

631

632

633

634

635

636

637

638

639

640

641

642

643

644

645

646

647

648

649

650

651

652

653

654

655

656

657

658

659

660

661

662

663

664

665

666

667

668

669

670

671

1. Ruiz-Agudo, E., et al., A non-classical view on calcium oxalate precipitation and the role of citrate. Nat Commun, 2017. 8(1): p. 768.

2. Asplin, J., et al., Supersaturation and stone composition in a network of dispersed treatment sites. J Urol., 1998. 159(6): p. 1821-1825.

3. Beck, B.B., et al., Hyperoxaluria and systemic oxalosis: an update on current therapy and future directions. Expert Opin Investig Drugs, 2013. 22(1): p. 117-29.

4. Mookadam, F., et al., Cardiac abnormalities in primary hyperoxaluria. Circ J, 2010. 74(11): p. 2403-9.

5. Punjabi, O.S., K. Riaz, and M.B. Mets, Crystalline retinopathy in primary hyperoxaluria. J AAPOS, 2011. 15(2): p. 214-6.

6. Lieske, J.C., et al., Stone composition as a function of age and sex. Clin J Am Soc Nephrol, 2014. 9(12): p. 2141-6.

7. Stamatelou, K.K., et al., Time trends in reported prevalence of kidney stones in the United States: 1976-1994. Kidney Int, 2003. 63(5): p. 1817-23.

8. Scales, C.D., et al., Prevalence of kidney stones in the United States. Eur Urol, 2012. 62(1): p. 160-5.

9. Rule, A.D., et al., The ROKS nomogram for predicting a second symptomatic stone episode. J Am Soc Nephrol, 2014. 25(12): p. 2878-86.

10. Scales, C.D., Jr., et al., Prevalence of kidney stones in the United States. Eur Urol, 2012. 62(1): p. 160-5.

11. Knauf, $F$., et al., NALP3-mediated inflammation is a principal cause of progressive renal failure in oxalate nephropathy. Kidney Int, 2013. 84(5): p. 895-901.

12. Mulay, S.R., et al., Oxalate-induced chronic kidney disease with its uremic and cardiovascular complications in C57BL/6 mice. Am J Physiol Renal Physiol, 2016. 310(8): p. F785-F795.

13. Waikar, S.S., et al., Association of Urinary Oxalate Excretion With the Risk of Chronic Kidney Disease Progression. JAMA Intern Med, 2019.

14. Mulay, S.R., et al., Calcium oxalate crystals induce renal inflammation by NLRP3mediated IL-1beta secretion. J Clin Invest, 2013. 123(1): p. 236-46.

15. Barber, H.H. and E.J. Gallimore, The metabolism of oxalic acid in the animal body. Biochem J, 1940. 34(2): p. 144-8.

16. Allison, M.J., et al., Oxalate degradation by gastrointestinal bacteria from humans. J Nutr, 1986. 116(3): p. 455-60.

17. Allison, M.J. and H.M. Cook, Oxalate degradation by microbes of the large bowel of herbivores: the effect of dietary oxalate. Science, 1981. 212(4495): p. 675-676.

18. Allison, M.J., E.T. Littledike, and L.F. James, Changes in ruminal oxalate degradation rates associated with adaptation to oxalate ingestion. J Anim Sci., 1977. 45(5): p. 11731179.

19. Tasian, G.E., et al., Oral Antibiotic Exposure and Kidney Stone Disease. J Am Soc Nephrol, 2018.

20. Ferraro, P.M., et al., Antibiotic Use and Risk of Incident Kidney Stones in Female Nurses. Am J Kidney Dis, 2019.

21. Nazzal, L. and M.J. Blaser, Does the Receipt of Antibiotics for Common Infectious Diseases Predispose to Kidney Stones? A Cautionary Note for All Health Care Practitioners. J Am Soc Nephrol, 2018. 29(6): p. 1590-1592.

22. Abratt, V.R. and S.J. Reid, Oxalate-degrading bacteria of the human gut as probiotics in the management of kidney stone disease. Adv Appl Microbiol, 2010. 72: p. 63-87.

23. Allison, M.J., et al., Oxalobacter formigenes gen. nov., sp. nov.: oxalate-degrading anaerobes that inhabit the gastrointestinal tract. Arch Microbiol, 1985. 141(1): p. 1-7. 
medRxiv preprint doi: https://doi.org/10.1101/2020.01.27.20018770; this version posted January 29, 2020. The copyright holder for this preprint (which was not certified by peer review) is the author/funder, who has granted medRxiv a license to display the preprint in perpetuity. It is made available under a CC-BY-NC 4.0 International license .

672

673

674

675

676

677

678

679

680

681

682

683

684

685

686

687

688

689

690

691

692

693

694

695

696

697

698

699

700

701

702

703

704

705

706

707

708

709

710

711

712

713

714

715

716

717

718

719

720

721

722

723

724

725

24. Dawson, K.A., M.J. Allison, and P.A. Hartman, Isolation and some characteristics of anaerobic oxalate-degrading bacteria from the rumen. Applied and environmental microbiology, 1980. 40(4): p. 833-839.

25. Ruan, Z.-S., et al., Identification, purification, and reconstitution of OxIT, the oxalate: formate antiport protein of Oxalobacter formigenes. Journal of Biological Chemistry, 1992. 267(15): p. 10537-10543.

26. Lung, H.-y., J.G. Cornelius, and A.B. Peck, Cloning and expression of the oxalyl-CoA decarboxylase gene from the bacterium, Oxalobacter formigenes: prospects for gene therapy to control Ca-oxalate kidney stone formation. American journal of kidney diseases, 1991. 17(4): p. 381-385.

27. Baetz, A.L. and M.J. Allison, Purification and characterization of formyl-coenzyme A transferase from Oxalobacter formigenes. Journal of bacteriology, 1990. 172(7): p. 35373540.

28. Hoppe, B., et al., Efficacy and safety of Oxalobacter formigenes to reduce urinary oxalate in primary hyperoxaluria. Nephrol Dial Transplant, 2011. 26(11): p. 3609-15.

29. Hoppe, B., et al., A randomised Phase I/II trial to evaluate the efficacy and safety of orally administered Oxalobacter formigenes to treat primary hyperoxaluria. Pediatr Nephrol, 2017. 32(5): p. 781-790.

30. Hatch, M. and R.W. Freel, $A$ human strain of Oxalobacter (HC-1) promotes enteric oxalate secretion in the small intestine of mice and reduces urinary oxalate excretion. Urolithiasis, 2013. 41(5): p. 379-84.

31. Arvans, D., et al., Oxalobacter formigenes-Derived Bioactive Factors Stimulate Oxalate Transport by Intestinal Epithelial Cells. J Am Soc Nephrol, 2017. 28(3): p. 876-887.

32. Li, X., M.L. Ellis, and J. Knight, Oxalobacter formigenes Colonization and Oxalate Dynamics in a Mouse Model. Applied and Environmental Microbiology, 2015. 81(15): p. 5048-5054.

33. Li, X., et al., Response of Germfree Mice to Colonization by Oxalobacter formigenes and Altered Schaedler Flora. Applied and environmental microbiology, 2016. 82(23): p. 69526960.

34. Azcarate-Peril, M.A., et al., Transcriptional and functional analysis of oxalyl-coenzyme A (CoA) decarboxylase and formyl-CoA transferase genes from Lactobacillus acidophilus. Appl Environ Microbiol, 2006. 72(3): p. 1891-9.

35. Turroni, S., et al., Oxalate consumption by lactobacilli: evaluation of oxalyl-CoA decarboxylase and formyl-CoA transferase activity in Lactobacillus acidophilus. J Appl Microbiol, 2007. 103(5): p. 1600-9.

36. Lewanika, T.R., et al., Lactobacillus gasseri Gasser AM63(T) degrades oxalate in a multistage continuous culture simulator of the human colonic microbiota. FEMS Microbiol Ecol, 2007. 61(1): p. 110-20.

37. Ferraz, R.R., et al., Effects of Lactobacillus casei and Bifidobacterium breve on urinary oxalate excretion in nephrolithiasis patients. Urol Res, 2009. 37(2): p. 95-100.

38. Kolandaswamy, A., L. George, and S. Sadasivam, Heterologous expression of oxalate decarboxylase in Lactobacillus plantarum NC8. Curr Microbiol, 2009. 58(2): p. 117-21.

39. Sasikumar, P., et al., Secretion of biologically active heterologous oxalate decarboxylase (OxdC) in Lactobacillus plantarum WCFS1 using homologous signal peptides. Biomed Res Int, 2013. 2013: p. 280432.

40. Miller, A.W., K.D. Kohl, and M.D. Dearing, The Gastrointestinal Tract of the WhiteThroated Woodrat (Neotoma albigula) Harbors Distinct Consortia of Oxalate-Degrading Bacteria. Applied and Environmental Microbiology, 2014. 80(5): p. 1595-1601.

41. Kullin, B., et al., A functional analysis of the formyl-coenzyme $A$ (frc) gene from Lactobacillus reuteri 100-23C. J Appl Microbiol, 2014. 116(6): p. 1657-67.

42. Turroni, S., et al., Oxalate-degrading activity in Bifidobacterium animalis subsp. lactis: impact of acidic conditions on the transcriptional levels of the oxalyl coenzyme $A$ (CoA) decarboxylase and formyl-CoA transferase genes. Appl Environ Microbiol, 2010. 76(16): p. 5609-20. 
medRxiv preprint doi: https://doi.org/10.1101/2020.01.27.20018770; this version posted January $29,2020$. The copyright holder for this preprint (which was not certified by peer review) is the author/funder, who has granted medRxiv a license to display the preprint in perpetuity. It is made available under a CC-BY-NC 4.0 International license .

726

727

728

729

730

731

732

733

734

735

736

737

738

739

740

741

742

743

744

745

746

747

748

749

750

751

752

753

754

755

756

757

758

759

760

761

762

763

764

765

766

767

768

769

770

771

772

773

774

775

776

777

778

779

43. Klimesova, K., J.M. Whittamore, and M. Hatch, Bifidobacterium animalis subsp. lactis decreases urinary oxalate excretion in a mouse model of primary hyperoxaluria. Urolithiasis, 2015. 43(2): p. 107-17.

44. McConnell, N., et al., Risk factors for developing renal stones in inflammatory bowel disease. BJU Int, 2002. 89(9): p. 835-41.

45. Corica, D. and C. Romano, Renal Involvement in Inflammatory Bowel Diseases. J Crohns Colitis, 2016. 10(2): p. 226-35.

46. Liu, M. and L. Nazzal, Enteric hyperoxaluria: role of microbiota and antibiotics. Curr Opin Nephrol Hypertens, 2019. 28(4): p. 352-359.

47. Daniel, S.L., C. Pilsl, and H.L. Drake, Oxalate metabolism by the acetogenic bacterium Moorella thermoacetica. FEMS Microbiol Lett, 2004. 231(1): p. 39-43.

48. Pierce, E., D.F. Becker, and S.W. Ragsdale, Identification and characterization of oxalate oxidoreductase, a novel thiamine pyrophosphate-dependent 2-oxoacid oxidoreductase that enables anaerobic growth on oxalate. J Biol Chem, 2010. 285(52): p. 40515-24.

49. Allison, M.J., et al., Oxalobacter formigenes gen. nov., sp. nov.: oxalate-degrading anaerobes that inhabit the gastrointestinal tract. Arch.Microbiol., 1985. 141(1): p. 1-7.

50. Blackmore, M.A. and J.R. Quayle, Microbial growth on oxalate by a route not involving glyoxylate carboligase. Biochem J, 1970. 118(1): p. 53-9.

51. Dumas, B., et al., Identification of barley oxalate oxidase as a germin-like protein. C R Acad Sci III, 1993. 316(8): p. 793-8.

52. Anand, R., et al., Structure of oxalate decarboxylase from Bacillus subtilis at $1.75 \mathrm{~A}$ resolution. Biochemistry, 2002. 41(24): p. 7659-69.

53. Foster, J., et al., A previously unknown oxalyl-CoA synthetase is important for oxalate catabolism in Arabidopsis. Plant Cell, 2012. 24(3): p. 1217-29.

54. Moussatche, P., et al., Characterization of Ceriporiopsis subvermispora bicupin oxalate oxidase expressed in Pichia pastoris. Arch Biochem Biophys, 2011. 509(1): p. 100-7.

55. Moomaw, E.W., et al., Kinetic and spectroscopic studies of bicupin oxalate oxidase and putative active site mutants. PLoS One, 2013. 8(3): p. e57933.

56. Moomaw, E.W., R. Uberto, and C. Tu, Membrane inlet mass spectrometry reveals that Ceriporiopsis subvermispora bicupin oxalate oxidase is inhibited by nitric oxide. Biochem Biophys Res Commun, 2014. 450(1): p. 750-4.

57. Rana, H., et al., Isothermal titration calorimetry uncovers substrate promiscuity of bicupin oxalate oxidase from Ceriporiopsis subvermispora. Biochem Biophys Rep, 2016. 5: p. 396-400.

58. Burrell, M.R., et al., Oxalate decarboxylase and oxalate oxidase activities can be interchanged with a specificity switch of up to 282,000 by mutating an active site lid. Biochemistry, 2007. 46(43): p. 12327-36.

59. Mitchell, A.L., et al., InterPro in 2019: improving coverage, classification and access to protein sequence annotations. Nucleic Acids Res, 2019. 47(D1): p. D351-D360.

60. Mulder, N.J., et al., InterPro, progress and status in 2005. Nucleic Acids Res, 2005. 33(Database issue): p. D201-5.

61. Buchfink, B., C. Xie, and D.H. Huson, Fast and sensitive protein alignment using DIAMOND. Nat Methods, 2015. 12(1): p. 59-60.

62. Fontenot, E.M., et al., YfdW and $Y f d U$ are required for oxalate-induced acid tolerance in Escherichia coli K-12. J Bacteriol, 2013. 195(7): p. 1446-55.

63. Cho, J.G., et al., Assessment of in vitro oxalate degradation by Lactobacillus species cultured from veterinary probiotics. Am J Vet Res, 2015. 76(9): p. 801-6.

64. Mogna, L., et al., Screening of different probiotic strains for their in vitro ability to metabolise oxalates: any prospective use in humans? J Clin Gastroenterol, 2014. 48 Suppl 1: p. S91-5.

65. Gruez, A., et al., The crystal structure of the Escherichia coli YfdW gene product reveals a new fold of two interlaced rings identifying a wide family of CoA transferases. J Biol Chem, 2003. 278(36): p. 34582-6. 
medRxiv preprint doi: https://doi.org/10.1101/2020.01.27.20018770; this version posted January 29, 2020. The copyright holder for this preprint (which was not certified by peer review) is the author/funder, who has granted medRxiv a license to display the preprint in perpetuity. It is made available under a CC-BY-NC 4.0 International license .

780 66. Federici, F., et al., Characterization and heterologous expression of the oxalyl coenzyme A decarboxylase gene from Bifidobacterium lactis. Appl Environ Microbiol, 2004. 70(9): p. 5066-73.

67. Cornick, N.A. and M.J. Allison, Assimilation of oxalate, acetate, and CO2 by Oxalobacter formigenes. Can J Microbiol, 1996. 42(11): p. 1081-6.

68. Allison, M.J., et al., Oxalate degradation by gastrointestinal bacteria from humans. J Nutr., 1986. 116(3): p. 455-460.

69. Barnett, C., et al., The presence of Oxalobacter formigenes in the microbiome of healthy young adults. The Journal of urology, 2016. 195(2): p. 499-506.

70. Liu, M., et al., Oxalobacter formigenes-associated host features and microbial community structures examined using the American Gut Project. Microbiome, 2017. 5(1): p. 108.

71. Kelly, J.P., et al., Factors related to colonization with Oxalobacter formigenes in U.S. adults. J Endourol, 2011. 25(4): p. 673-9.

72. PeBenito, A., et al., Comparative prevalence of Oxalobacter formigenes in three human populations. Sci Rep, 2019. 9(1): p. 574.

73. Cury, D.B., A.C. Moss, and N. Schor, Nephrolithiasis in patients with inflammatory bowel disease in the community. Int J Nephrol Renovasc Dis, 2013. 6: p. 139-42.

74. Franzosa, E.A., et al., Gut microbiome structure and metabolic activity in inflammatory bowel disease. Nat Microbiol, 2019. 4(2): p. 293-305.

75. Lloyd-Price, J., et al., Multi-omics of the gut microbial ecosystem in inflammatory bowel diseases. Nature, 2019. 569(7758): p. 655-662.

76. Daniel, S.L., P.A. Hartman, and M.J. Allison, Intestinal colonization of laboratory rats with Oxalobacter formigenes. Appl.Environ.Microbiol., 1987. 53(12): p. 2767-2770.

77. Daniel, S.L., P.A. Hartman, and M.J. Allison, Microbial degradation of oxalate in the gastrointestinal tracts of rats. Appl.Environ.Microbiol., 1987. 53(8): p. 1793-1797.

78. Ticinesi, A., A. Nouvenne, and T. Meschi, Gut microbiome and kidney stone disease: not just an Oxalobacter story. Kidney Int, 2019. 96(1): p. 25-27.

79. Miller, A.W., et al., Inhibition of urinary stone disease by a multi-species bacterial network ensures healthy oxalate homeostasis. Kidney Int, 2019. 96(1): p. 180-188.

80. Ticinesi, A., et al., Understanding the gut-kidney axis in nephrolithiasis: an analysis of the gut microbiota composition and functionality of stone formers. Gut, 2018. 67(12): p. 2097-2106.

81. Stern, J.M., et al., Evidence for a distinct gut microbiome in kidney stone formers compared to non-stone formers. Urolithiasis, 2016. 44(5): p. 399-407.

82. Ellis, M.E., et al., Proteome Dynamics of the Specialist Oxalate Degrader Oxalobacter formigenes. J Proteomics Bioinform, 2016. 9(1): p. 19-24.

83. Halbritter, J., et al., Fourteen monogenic genes account for $15 \%$ of nephrolithiasis/nephrocalcinosis. J Am Soc Nephrol, 2015. 26(3): p. 543-51.

84. Hylander, E., S. Jarnum, and I. Frandsen, Urolithiasis and hyperoxaluria in chronic inflammatory bowel disease. Scand J Gastroenterol, 1979. 14(4): p. 475-9.

85. Hylander, E., et al., Enteric hyperoxaluria: dependence on small intestinal resection, colectomy, and steatorrhoea in chronic inflammatory bowel disease. Scand $\mathrm{J}$ Gastroenterol, 1978. 13(5): p. 577-88.

86. Hoppe, B., et al., Oxalobacter formigenes: a potential tool for the treatment of primary hyperoxaluria type 1. Kidney Int, 2006. 70(7): p. 1305-11.

87. Hoppe, B., et al., Oxalate degrading bacteria: new treatment option for patients with primary and secondary hyperoxaluria? Urological Research, 2005. 33(5): p. 372-375.

88. Canales, B.K. and M. Hatch, Oxalobacter formigenes colonization normalizes oxalate excretion in a gastric bypass model of hyperoxaluria. Surg Obes Relat Dis, 2017. 13(7): p. $1152-1157$.

89. Hatch, M., et al., Oxalobacter sp. reduces urinary oxalate excretion by promoting enteric oxalate secretion. Kidney Int, 2006. 69(4): p. 691-8. 
medRxiv preprint doi: https://doi.org/10.1101/2020.01.27.20018770; this version posted January $29,2020$. The copyright holder for this preprint (which was not certified by peer review) is the author/funder, who has granted medRxiv a license to display the preprint in perpetuity.

It is made available under a CC-BY-NC 4.0 International license .

$83390 . \mathrm{Li}$, J., et al., An integrated catalog of reference genes in the human gut microbiome. Nat Biotechnol, 2014. 32(8): p. 834-41.

91. Ehrlich, S.D., MetaHIT: The European Union Project on Metagenomics of the Human Intestinal Tract, in Metagenomics of the Human Body, K.E. Nelson, Editor. 2011, Springer New York: New York, NY. p. 307-316.

92. Franzosa, E.A., et al., Relating the metatranscriptome and metagenome of the human gut. Proc Natl Acad Sci U S A, 2014. 111(22): p. E2329-38.

93. Petersen, L.M., et al., Community characteristics of the gut microbiomes of competitive cyclists. Microbiome, 2017. 5(1): p. 98.

94. Abu-Ali, G.S., et al., Metatranscriptome of human faecal microbial communities in a cohort of adult men. Nat Microbiol, 2018. 3(3): p. 356-366.

95. Schirmer, M., et al., Dynamics of metatranscription in the inflammatory bowel disease gut microbiome. Nat Microbiol, 2018. 3(3): p. 337-346.

96. Franzosa, E.A., et al., Species-level functional profiling of metagenomes and metatranscriptomes. Nat Methods, 2018. 15(11): p. 962-968.

97. Graz, M., et al., Oxalic acid degradation by a novel fungal oxalate oxidase from Abortiporus biennis. Acta Biochim Pol, 2016. 63(3): p. 595-600.

98. Kumar, R., V. Hooda, and C.S. Pundir, Purification and partial characterization of oxalate oxidase from leaves of forage Sorghum (Sorghum vulgare var. $\mathrm{KH}-105)$ seedlings. Indian J Biochem Biophys, 2011. 48(1): p. 42-6.

99. Svedruzic, D., et al., Investigating the roles of putative active site residues in the oxalate decarboxylase from Bacillus subtilis. Arch Biochem Biophys, 2007. 464(1): p. 36-47.

100. Just, V.J., et al., A closed conformation of Bacillus subtilis oxalate decarboxylase OxdC provides evidence for the true identity of the active site. J Biol Chem, 2004. 279(19): p. 19867-74.

101. Tanner, A., et al., Oxalate decarboxylase requires manganese and dioxygen for activity. Overexpression and characterization of Bacillus subtilis YvrK and YoaN. J Biol Chem, 2001. 276(47): p. 43627-34.

102. Edgar, R.C., MUSCLE: multiple sequence alignment with high accuracy and high throughput. Nucleic Acids Res, 2004. 32(5): p. 1792-7.

103. Gouy, M., S. Guindon, and O. Gascuel, SeaView version 4: A multiplatform graphical user interface for sequence alignment and phylogenetic tree building. Mol Biol Evol, 2010. 27(2): p. 221-4.

104. Charif, D., et al., Online synonymous codon usage analyses with the ade4 and seqinR packages. Bioinformatics, 2005. 21(4): p. 545-7.

105. Fitch, W.M., An improved method of testing for evolutionary homology. J Mol Biol, 1966. 16(1): p. 9-16.

106. Kurtz, Z.D., et al., Sparse and Compositionally Robust Inference of Microbial Ecological Networks. PLOS Computational Biology, 2015. 11(5): p. e1004226. 